\title{
Enterococcus faecalis Countermeasures Defeat a Virulent Picovirinae Bacteriophage
}

\author{
Julien Lossouarn 1,*®D, Arnaud Briet ${ }^{1}$, Elisabeth Moncaut ${ }^{1}$, Sylviane Furlan ${ }^{1}$, Astrid Bouteau ${ }^{1}$, \\ Olivier Son ${ }^{1}$, Magali Leroy ${ }^{2}$, Michael S. DuBow ${ }^{2}$, François Lecointe ${ }^{1}$, Pascale Serror ${ }^{1}$ (D) and \\ Marie-Agnès Petit ${ }^{1}$ \\ 1 Micalis Institute, INRA, AgroParisTech, Université Paris-Saclay, 78350 Jouy-en-Josas, France; \\ Arnaud.Briet@ANSES.FR (Ar.B.); elisabeth.moncaut@inra.fr (E.M.); sylviane.furlan@inra.fr (S.F.); \\ astridbouteau@gmail.com (As.B.); olivier.son@inra.fr (O.S.); françois.lecointe@inra.fr (F.L.); \\ pascale.serror@inra.fr (P.S.); marie-agnes.petit@inra.fr (M.-A.P.) \\ 2 Institute for Integrative Biology of the Cell (I2BC), CEA, CNRS, Université Paris-Sud, Université Paris-Saclay, \\ 91198 Gif-sur-Yvette, France; magali.o.leroy@gmail.com (M.L.); micheal.dubow@igmors.u-psud.fr (M.S.D.) \\ * Correspondence: julien.lossouarn@inra.fr; Tel.: +33-(0)1-34-65-28-67
}

Received: 14 December 2018; Accepted: 31 December 2018; Published: 10 January 2019

check for updates

\begin{abstract}
Enterococcus faecalis is an opportunistic pathogen that has emerged as a major cause of nosocomial infections worldwide. Many clinical strains are indeed resistant to last resort antibiotics and there is consequently a reawakening of interest in exploiting virulent phages to combat them. However, little is still known about phage receptors and phage resistance mechanisms in enterococci. We made use of a prophageless derivative of the well-known clinical strain E. faecalis V583 to isolate a virulent phage belonging to the Picovirinae subfamily and to the P68 genus that we named Idefix. Interestingly, most isolates of E. faecalis tested-including V583-were resistant to this phage and we investigated more deeply into phage resistance mechanisms. We found that E. faecalis V583 prophage 6 was particularly efficient in resisting Idefix infection thanks to a new abortive infection (Abi) mechanism, which we designated Abi $\alpha$. It corresponded to the Pfam domain family with unknown function DUF4393 and conferred a typical Abi phenotype by causing a premature lysis of infected E. faecalis. The abia gene is widespread among prophages of enterococci and other Gram-positive bacteria. Furthermore, we identified two genes involved in the synthesis of the side chains of the surface rhamnopolysaccharide that are important for Idefix adsorption. Interestingly, mutants in these genes arose at a frequency of $\sim 10^{-4}$ resistant mutants per generation, conferring a supplemental bacterial line of defense against Idefix.
\end{abstract}

Keywords: abortive infection; prophage; adsorption; Enterococcus; rhamnopolysaccharide

\section{Introduction}

Enterococci are ubiquitous Gram-positive facultative anaerobic bacteria that colonize the mammalian gastrointestinal tract [1]. In particular, the two species Enterococcus faecalis and Enterococcus faecium are part of the normal human gut microbiota and generally have no adverse effects on healthy individuals. However, they also represent opportunistic pathogens that have emerged as a leading source of nosocomial infections, particularly in immunocompromised patients [2]. E. faecalis and E. faecium mostly cause urinary tract infections, peritonitis, bacteraemia, and endocarditis [2]. The clinical importance of these bacterial species is directly related to their antibiotic resistance. The rapid spread of clinical isolates resistant to last resort antibiotics such as vancomycin and daptomycin has been of particular concern and associated hospital acquired infections have become a growing problem [3]. 
Virulent bacteriophages, i.e., viruses that infect and obligatorily lyse bacteria, have long held promise to treat bacterial infections and combat multi-drug resistant (MDR) bacteria [4]. In the recent years, the complete genome and phage cycle characteristics of a dozen virulent $E$. faecalis and E. faecium phages have been reported, emphasizing the growing interest for phage therapy in the future [5-15]. However, similar to the phenomenon of antibiotic resistance, bacterial resistance to phage is also taking place. For instance, mutations in the cell wall protein $\mathrm{PIP}_{\mathrm{EF}}$ were recently found to provide resistance to two siphophages by limiting phage DNA entry in E. faecalis [16]. Apart from this, the modes of defence of enterococci against phages largely remain a terra incognita.

Keeping in mind that, in most ecosystems, bacteria co evolve with a plethora of bacteriophages, which imperatively depend on them for their reproduction, it is no surprise that bacteria invest efforts in fighting against them. They deploy for this goal different functions that have been studied for decades (reviewed in [17,18]), and still led to new discoveries [19-23]. The E. faecalis species, however, seems to have few acquired and innate immune systems. The only common clustered regularly interspaced short palindromic repeat (CRISPR)-CRISPR associated (Cas) locus found in E. faecalis isolates has lost its cas genes, and two complete type II CRISPR-Cas systems occur variably across the species [24-26]. Furthermore, no restriction-modification (R-M) system is commonly found within the species, and to date only a single type II R-M system has been described in three E. faecalis chromosomes [27,28]. Finally, no complete defense island system associated with restriction-modification was detected in E. faecalis to date [22]. The relative scarcity of R-M and CRISPR-Cas systems in MDR strains may facilitate plasmid-encoded antibiotic resistance genes acquisition $[29,30]$.

Although less studied, phages themselves compete for their hosts on the bacterial battlefield [31]. Phage genes involved in anti-phage mechanisms are mainly found in temperate or defective prophages, rather than in virulent phages. During the prophage state (where the temperate phage is stably associated with its host), in addition to repressor-dependent immunity against similar phages, some phage express genes conferring resistance to infection by more or less unrelated phages. These genes can encode generalist functions such as R-M systems [32] or CRISPR-Cas loci [33], or specific ones. For instance, the Escherichia coli temperate phage P2 has three genes, fun, tin, and old, preventing growth of T5, T-even, and lambda respectively [34]. Furthermore, the O-antigen acetylase of Salmonella typhimurium phage BTP1 is reported to prevent adsorption of other phages [35]. Other typical prophage-encoded superinfection exclusion (Sie) systems act to block phage DNA injection into E. coli [36], Lactococcus lactis [37], and Streptococcus thermophilus [38]. Similar systems have also been recently discovered in Pseudomonas [39] and Mycobacterium prophages [40].

Prophages can also encode abortive infection (Abi) mechanisms that cause an interruption of invasive phage development and a premature death of the infected bacteria. This leads to the release of few or no progeny particles and thus prevents the expansion of the infection to the neighboring bacteria $[17,18]$. Abi are very diverse; among those carried by prophages, some have been well characterized such as the two component Rex system preventing lambda-lysogenic E. coli strain infection by T4 phage [41] or the tyrosine kinase Stk of coliphage 933W that blocks the replication cycle of HK97 [41,42].

Our earlier work showed that the vancomycin-resistant E. faecalis V583 clinical isolate hosts seven prophage elements. One prophage is remnant and completely domesticated (prophage 2 ) while the six others have various degrees of autonomy and different levels of interference with each other [43]. Only three of them-prophages 1,3, and 5-are fully active and grow as plaques on a V583 derivative cured of all six prophages. However, prophage 1 is parasitized during the induction of it lytic cycle by the satellite prophage 7 also named a phage inducible chromosomal island. Prophages 4 and 6 finally retain some phage-like behavior but no longer produce infective virions. They excise from the bacterial chromosome in a process controlled by the other prophages, and once excised, prophage 4 replicates, while prophage 6 cannot [43].

To investigate putative anti-phage roles played by V583 prophages, we performed a phage screening using the V583 derivative strain cured of all plasmids and the six active prophages. We 
isolated a virulent phage belonging to the Picovirinae subfamily and to the P68 genus that contains phages with small size genome $(19-20 \mathrm{~kb})$. This prompted us to name this phage Idefix, after the French name of the small dog from Asterix comics. The genome sequence of two phages similar to Idefix have been reported recently $[13,44]$. We showed that E. faecalis prophage 6 , which apparently belongs to the Siphoviridae family, is especially efficient in resisting to Idefix infection due to a new abortive infection system that we call Abi $\alpha$. This latter confers a typical Abi phenotype, by causing a premature lysis of infected $E$. faecalis. The abia gene is notably widespread among prophages integrated in enterococci and other Gram-positive bacteria. Furthermore, the bacterium itself provides another line of defence against Idefix through efficient mutagenesis of the phage bacterial receptor encoded within the variable part of the epa locus responsible for the building up of the surface rhamnopolysaccharide of $E$. faecalis.

\section{Materials and Methods}

\subsection{Sample for Bacteriophage Isolation, Bacterial Strains, Plasmids, and Growth Conditions}

One raw sewage water sample from the Sèvres wastewater treatment plant (Paris area, France) was used as a source of phage. E. faecalis indicator strain (cured of active prophages (strain VE18590)) used for phage Idefix isolation, as well as strains and plasmids used for E. faecalis phage-resistance characterization are listed in Table S1 (with supplementary references [45-50]). Enterococcus strains tested to determine phage Idefix host range are detailed in Table S2 (with supplementary references $[51,52])$. E. coli was cultivated at $37^{\circ} \mathrm{C}$ in LB medium with shaking. L. lactis was grown statically at $30{ }^{\circ} \mathrm{C}$ in M17 medium supplemented with glucose $0.5 \%$ (M17G). Enterococcus strains were cultivated statically at $37^{\circ} \mathrm{C}$ either in BHI medium or in M17G medium. Following antibiotics were added when necessary: erythromycin, $10 \mu \mathrm{g} \cdot \mathrm{mL}^{-1}$ for E. faecalis and $100 \mu \mathrm{g} \cdot \mathrm{mL}^{-1}$ for L. lactis and E. coli strains; chloramphenicol, $20 \mu \mathrm{g} \cdot \mathrm{mL}^{-1}$ and $10 \mu \mathrm{g} \cdot \mathrm{mL}^{-1}$ for E. coli and E. faecalis strains, respectively; kanamycin, $50 \mu \mathrm{g} \cdot \mathrm{mL}^{-1}$ for E. coli strains.

\subsection{Phage Isolation}

Phage Idefix was isolated using the standard double overlay plaque assay technique as previously described [44] with minor modifications. A standard Petri dish was filled with 20-30 mL of BHI medium containing agar $1.5 \%$ and $\mathrm{MgSO}_{4} 10 \mathrm{mM}$. One hundred microliters of $0.45 \mu \mathrm{m}$ filtered sewage was mixed with $500 \mu \mathrm{L}$ of an overnight culture of the indicator strain, then added to $5 \mathrm{~mL}$ of $\mathrm{BHI}$ medium containing agarose $0.4 \%$ and $\mathrm{MgSO}_{4} 10 \mathrm{mM}$, and poured onto the bottom agar. The double agar/agarose plate was incubated $24 \mathrm{~h}$ at $37^{\circ} \mathrm{C}$ and screened for plaque appearance. Many different plaques were obtained, and among them, a large clear plaque was picked and streaked on an agar base before applying the second layer of BHI top agarose mixed with the overnight culture of the indicator strain. The plate was incubated $24 \mathrm{~h}$ at $37^{\circ} \mathrm{C}$ and a large clear plaque was streaked again twice, to ensure phage purity.

\subsection{Phage Concentration and Purification}

Starting from a large clear plaque, virions were resuspended in $1 \mathrm{~mL}$ of SM buffer (Tris- $\mathrm{HCl}$ $10 \mathrm{mM} \mathrm{pH} 7.5, \mathrm{MgSO}_{4} 10 \mathrm{mM}, \mathrm{NaCl} 300 \mathrm{mM}$ ) and the suspension was centrifuged $10 \mathrm{~min}$ at $7500 \times \mathrm{g}$ and room temperature. Phage titer in the supernatant was determined by preparing serial dilutions in SM buffer and using the double overlay method. High-titer phage stock was obtained as previously described [53] with slight modifications. Five hundred to one thousand phages were plated using the double overlay method, which led to a confluent lysis after $12 \mathrm{~h}$ at $37^{\circ} \mathrm{C}$. The plate was then flooded with $5 \mathrm{~mL}$ of SM buffer and incubated $2 \mathrm{~h}$ at $4{ }^{\circ} \mathrm{C}$. The overlay was carefully collected and centrifuged $20 \mathrm{~min}$ at $7500 \times \mathrm{g}$ at room temperature and the phages-containing supernatant was passed through a $0.45 \mu \mathrm{m}$ filter. Phage stocks were titrated $\left(\sim 10^{11} \mathrm{PFU} \cdot \mathrm{mL}^{-1}\right)$ and stored at $4{ }^{\circ} \mathrm{C}$ for further experiments. Ten milliliters of filtered phage stock was incubated $12 \mathrm{~h}$ at $4{ }^{\circ} \mathrm{C}$ under stirring in the presence of $\mathrm{NaCl}$ $1 \mathrm{M}$ and PEG 8000 10\%. Precipitated phages were then centrifuged $20 \mathrm{~min}$ at $10,000 \times \mathrm{g}$ and $4{ }^{\circ} \mathrm{C}$ and 
slowly resuspended in $1 \mathrm{~mL}$ of SM buffer for $1 \mathrm{~h}$ at $4{ }^{\circ} \mathrm{C}$ prior to be purified by centrifugation in a $\mathrm{CsCl}$ buoyant gradient. The purified phage-containing fraction was then recovered (density 1.4), titrated and stored at $4{ }^{\circ} \mathrm{C}$ for further experiments.

\subsection{Phage Examination in Transmission Electron Microscopy}

Ten microliters of purified phage Idefix fraction were directly spotted onto a Formwar carbon coated copper grid. Phages were allowed to adsorb to the carbon layer for $5 \mathrm{~min}$ and excess of liquid was removed. Ten microliters of a staining uranyl acetate solution (1\%) was then spotted to the grid for $10 \mathrm{~s}$ and excess of liquid was removed again. The grid was imaged at $80 \mathrm{kV}$ in a Hitachi HT7700 transmission electron microscope.

\subsection{Phage Genomic Nucleic Acid Extraction, Whole Genome Sequencing, and Bioinformatic Analysis}

Total DNA was extracted as described in $[54,55]$. Prior to DNA extraction, $10 \mathrm{~mL}$ of the phage stock $\left(10^{11} \mathrm{PFU} \cdot \mathrm{mL}^{-1}\right)$ was treated with $40 \mu \mathrm{L}$ of nuclease mix ( $50 \%$ glycerol, $0.25 \mathrm{mg} \cdot \mathrm{mL}^{-1} \mathrm{RNAse}$ A, $0.25 \mathrm{mg} \cdot \mathrm{mL}^{-1}$ Dnase I, $150 \mathrm{mM} \mathrm{NaCl}$ ), for $15 \mathrm{~min}$ at $37^{\circ} \mathrm{C}$. Particles were then precipitated by adding PEG $8000(10 \%, w / v)$ and $\mathrm{NaCl}$ to $1 \mathrm{M}$, and let sit overnight at $4{ }^{\circ} \mathrm{C}$ once PEG was solubilized. Phages were centrifuged $10 \mathrm{~min}$ at $10,000 \times \mathrm{g}$ and room temperature, and resuspended into $500 \mu \mathrm{L}$ of SM buffer. Insoluble particles were removed by centrifugation $(20 \mathrm{~s}$ at $12,000 \times g)$, and the clarified supernatant was used for DNA extraction. The PROMEGA Wizard DNA Clean up kit (ref A7280) was then used, following essentially the manufacturer instructions. Prior to DNA elution from the column, a washing step with 5.4 M guanidium thiocyanate (resin solution) was applied. DNA was sent to a 454-sequencing platform, and reads were assembled with Newbler [56]. The phage genome was annotated using RAST [57], followed by manual inspection. The genome sequence is available under the accession number LT630001.1. All genomic figures, including Idefix genome comparison, were generated using Easyfig [58].

\subsection{Determination of Phage Burst Size}

The one-step growth kinetic curve of phage Idefix was measured using a standard method [59] with minor modifications. One milliliter of a log-phase culture of indicator strain was centrifuged 5 min at $10,000 \times g$ and room temperature, and resuspended in $100 \mu \mathrm{L}$ of prewarmed BHI medium with $\mathrm{MgSO}_{4}(10 \mathrm{mM})$. Phage from the high-titer phage stock was added at a MOI of 0.001 and allowed to adsorb for $5 \mathrm{~min}$ at $37^{\circ} \mathrm{C}$. The phage/bacteria mix was centrifuged $2 \mathrm{~min}$ at $10,000 \times \mathrm{g}$ and room temperature. The supernatant was titrated to count unadsorbed phage particles, whereas the bacterial pellet was washed in $100 \mu \mathrm{L}$ of prewarmed $\mathrm{BHI}$ medium with $\mathrm{MgSO}_{4}(10 \mathrm{mM})$ and recentrifuged. The pellet was suspended and diluted in $10 \mathrm{~mL}$ of prewarmed BHI medium with $\mathrm{MgSO}_{4}(10 \mathrm{mM})$ and cultured at $37^{\circ} \mathrm{C}$. Samples were taken at regular intervals and plated at the correct dilution for phage titration. A second set of samples from a synchronized 100-fold diluted culture was taken at same intervals and titrated. The values indicate the means and standard deviations of three independent experiments.

\subsection{Determination of Phage Host Range}

Ten microliters of serially diluted high-titer phage stock were spotted $(10 \mu \mathrm{L})$ on top of agarose overlays containing overnight culture of enterococci, as described above (Table S2). Plates were incubated at $37^{\circ} \mathrm{C}$ and examined for plaque appearance 6,12 , and $24 \mathrm{~h}$ after spotting.

\subsection{Determination of Phage Efficiency of Plaquing}

Efficiency of plaquing (EOP) was determined for E. faecalis derivative strains (Table S1). One hundred phages were plated using the double overlay plaque assay technique. EOP were calculated 
as $($ (phage titer on tested strain $\left.) \times(\text { phage titer on the indicator strain })^{-1}\right) \times 100$. These experiments were independently performed three times and average values are reported with standard deviations.

\subsection{Phage Adsorption Assay}

Adsorption of phage to E. faecalis derivative strains were determined as reported previously [60] with minor modifications. One milliliter of log-phase cultures was harvested and resuspended in $100 \mu \mathrm{L}$ of $\mathrm{BHI}$ medium with $\mathrm{MgSO}_{4}(10 \mathrm{mM})$, and then phage from the high-titer phage stock was added at a MOI of 0.001 . Following incubation for $10 \mathrm{~min}$ at $37^{\circ} \mathrm{C}$, the phage/bacteria mixtures were centrifuged $2 \mathrm{~min}$ at $10,000 \times g$ and room temperature. Supernatants were plated at the correct dilution and titrated for phage. Percentages of adsorption were calculated as ((control titer - residual titer) $\times$ $\left.(\text { control titer })^{-1}\right) \times 100$. These experiments were independently conducted three times and average values are given with standard deviations.

\subsection{Determination of Phage Efficiency of Center of Infection}

Efficiency of center of infection (ECOI) was determined for E. faecalis derivative strains as detailed by [61] with minor modifications. One milliliter of log-phase cultures was harvested and resuspended as previously, and then phage from the high-titer phage stock was added at a MOI of 0.001. Following incubation for $5 \mathrm{~min}$ at $37^{\circ} \mathrm{C}$, the phage/bacteria mixtures were centrifuged $1 \mathrm{~min}$ at $10,000 \times g$ and $4{ }^{\circ} \mathrm{C}$, washed twice, diluted, and assayed for infective centers. An E. faecalis strain which does not adsorb Idefix was used as control to monitor the effectiveness of phage removal during washing. Percentages of ECOI were calculated as ((number of centers on indicator strain) $\times$ (number of centers on tested strain $\left.)^{-1}\right) \times 100$. These experiments were independently performed three times and average values are reported with standard deviations.

\subsection{Bacterial Survival Assay}

E. faecalis derivative strains survival was assayed as essentially described in [62] with slight modifications. Briefly, one milliliter of log-phase bacterial cultures was harvested and resuspended as previously described, and then phage from the high-titer phage stock was added at both MOI of 1 and 10. Following incubation for $20 \mathrm{~min}$ at $37^{\circ} \mathrm{C}$, bacterial suspensions were plated at the correct dilution on agar plates and surviving bacteria were enumerated as CFU. Percentages of bacterial death were calculated as $\left(\left(\mathrm{CFU} \cdot \mathrm{mL}^{-1}\right.\right.$ in cultures without phage $-\mathrm{CFU} \cdot \mathrm{mL}^{-1}$ in cultures with phage $) \times$ $\left.\left(\mathrm{CFU} \cdot \mathrm{mL}^{-1} \text { in cultures without phage }\right)^{-1}\right) \times 100$. These experiments were independently conducted three times and average values are shown with standard deviations.

\subsection{Lysis Curve Experiments}

One milliliter of log-phase bacterial cultures was harvested and resuspended as previously described, and then phage from the high-titer phage stock was added at an MOI of 10. Following incubation for $10 \mathrm{~min}$ at $37^{\circ} \mathrm{C}$, the phage/bacteria mixtures were centrifuged $2 \mathrm{~min}$ at $10,000 \times g$ and room temperature. Pellets were resuspended in $200 \mu \mathrm{L}$ of $\mathrm{BHI}$ medium with $\mathrm{MgSO}_{4}(10 \mathrm{mM})$ and the suspensions were transferred in wells of a 96-wells plate. Empty wells are filled with BHI medium or uninfected bacterial suspensions to have negative and positive growth control respectively. Bacterial growths were then monitored during 30-50 min at $37^{\circ} \mathrm{C}$ using a Tecan plate reader (OD $600 \mathrm{~nm}$, measurements at 2 min intervals after shakings). During the experiment, each sample was prepared and monitored in triplicates. Kinetics shown are representative of three independent experiments.

\subsection{Luria-Delbrïck Fluctuation Tests}

An exponentially growing E. faecalis strain cured of prophage 6 (strain VE18306) culture supplemented with $10 \mathrm{mM} \mathrm{MgSO}_{4}$ was distributed in a 96-wells plate $(180 \mu \mathrm{L}$, corresponding to $\sim 2 \times 10^{4} \mathrm{CFU}$, in 93 wells), and infected with phage Idefix $\left(20 \mu \mathrm{L}\right.$, corresponding to $2 \times 10^{9} \mathrm{PFU}$, 
which are dispensed before bacteria, in 90 of the 96 wells). Remaining wells contained either BHI medium or uninfected VE18306 cultures. Following static incubation of the plates for $12 \mathrm{~h}$ at $37^{\circ} \mathrm{C}$, bacterial growth was evaluated using a Tecan plate reader, after a 1 min shaking step (OD $600 \mathrm{~nm}$ ). If mutations occur at random in the bacterial population, the number of mutational events per well follows a Poisson distribution [63], and the proportion of wells in which no mutant resisting to Idefix was present at the time of infection $\mathrm{P}_{0}$, is related to $\mathrm{h}$, the expectation of this law, by the formula $\mathrm{P}_{0}=$ $\mathrm{e}^{-\mathrm{h}}$. Knowing the average number of bacteria per well at infection, $\mathrm{N}$, mutation frequency $f=\mathrm{h} / \mathrm{N}$, so $f=-\ln _{0} / \mathrm{N}$. These experiments were independently performed three times giving a similar value of $f$.

\subsection{General Molecular Biology Methods}

All PCR reactions to clone or sequence IDF_13, IDF_15, ef2833, ef2847, ef2850, ef2169, and ef2170 genes were performed in a Mastercycler Eppendorf with Phusion high-fidelity DNA polymerase (NEB) and according to manufacturer's instructions. PCR products and DNA restriction fragments were purified with QIAquick kits (QIAGEN, Hilden, Germany) when necessary. Electro-transformation of E. coli, L. lactis, and E. faecalis were carried out as previously described [64,65] using a Gene Pulser apparatus (Bio-Rad Laboratories, Inc., Hercules, CA, USA). Transformations of chemically competent E. coli ER2566 were carried out by a heat shock procedure.

2.15. Cloning of IDF_13 and IDF_15, Expression and Preparation of Extracts of E. coli, and Spot Assay of the Extracts on the Indicator Strain

PCR amplification of IDF_13 and IDF_15 were performed using primer pairs OFL264/OFL265 and OFL266/267 respectively, with Idefix genomic DNA as template. PCR products were purified and digested by NdeI and BamHI restriction enzymes. Digested products were purified and cloned between the NdeI and BamHI sites of a linearized pJ411 derivative (Table S1). JM105 transformants were selected on LB plates supplemented with kanamycin. The resulting plasmids, pAB1and pAB2, contained the corresponding ORF fused in $5^{\prime}$ to a sequence coding for a His6-tag, placed under the control of a T7 promoter. His6-tagged IDF_13 and IDF_15 were produced in E. coli ER2566 transformed with pAB1 and pAB2 respectively. Cells were grown in $50 \mathrm{~mL}$ of LB supplemented with kanamycin at $37^{\circ} \mathrm{C}$. At $\mathrm{OD}_{600}=0.6$, production of the phage proteins was induced by addition of IPTG $(0.5 \mathrm{mM}$ final concentration) to the culture for $2.5 \mathrm{~h}$. Cells were then harvested by centrifugation at $5200 \times$ $g$ for $7 \mathrm{~min}$ at $4{ }^{\circ} \mathrm{C}$ and resuspended in $1 \mathrm{~mL}$ of lysis buffer (Tris- $\mathrm{HCl} 50 \mathrm{mM} \mathrm{pH} \mathrm{8,} \mathrm{NaCl} 150 \mathrm{mM}$ ). Cells suspensions were stored at $-20{ }^{\circ} \mathrm{C}$ until preparation of crude extracts. After thawing, bacteria were lyzed by sonication on ice. The lysates were centrifuged at $4{ }^{\circ} \mathrm{C}$ for $20 \mathrm{~min}$ at $20,000 \times g$ and the supernatants were stored at $-20^{\circ} \mathrm{C}$. Production and solubility of IDF_13 and IDF_15 were verified by SDS-PAGE. Lysis activity of IDF_13 and IDF_15 was assessed by spotting $5 \mu \mathrm{L}$ of the supernatants alone or a mix of both fractions on an indicator strain bacterial lawn as previously described.

2.16. Construction of E. faecalis VE18306 ef2833-, ef2847- and ef2850-Complemented Strains and E. faecalis VE18590 ef2833-Complemented Strain

Complementations of the prophage 6 genes ef2833, ef2847, and ef2850 were done using the pJIM2246 vector (Table S1). The three genes were amplified including their constitutive promoters and ribosome binding sites from DNA of $E$. faecalis strain containing all prophages (strain VE14089) with primer pairs JL12/JL13, JL10/JL11, and JL8/JL9 respectively (Table S1). The three purified products were separately cloned into pJIM2246 yielding plasmids pJL1, pJL2, and pJL3 after respective transformation into E. coli JM105 and chloramphenicol selection. pJL1, pJL2, and pJL3 were then separately electroporated into E. faecalis cured of prophage 6 (strain VE18306). The ef2833-, ef2847-, and ef2850-complemented strains were respectively selected on chloramphenicol. The nucleotide sequences of cloned PCR products were systematically confirmed by sequencing using primer pairs OEF879/1233 (Table S1). pJL3 and pJIM2246 were also separately electroporated into the indicator strain and selected as previously described. 


\subsection{PCR Amplification in epaX Region}

epaX region was amplified from total DNA of nine Idefix spontaneous resisting mutants using primer pairs OEF394/OEF397 and OEF527/OEF397 (Table S1). PCR analysis was extended for the three mutants for which no IS insertion was discovered with larger amplifications downstream and upstream epaX region using primer pairs OEF857/OEF527 and OEF885/OEF858; and OEF528/OEF856 and OEF859/OEF823 (Table S1) respectively.

\subsection{Construction of E. faecalis VE18306 $\mathrm{EepaX}$ Strain}

A deletion of epaX in the VE18306 background was constructed by double homologous recombination using pVE14283 plasmid (Table S1). pVE14283 was electroporated into strain VE18306, and the epaX deletion (strain VE18393, Table S1) was selected as described in $[49,66]$.

\subsection{Construction of E. faecalis VE18393 epaX—Complemented Strain}

A complementation of epaX was constructed using pVE14297 plasmid (Table S1). This latter, containing epaX under the control of the constitutive promoter $\mathrm{P}_{\mathrm{aphA} 3}$, was electroporated into the VE18306 $\triangle e p a X$ strain (strain VE18393) and the complementation (strain VE18945, Table S1) was selected as described in [49]. A control strain, harboring pVE14176 vector devoid of epaX, was also obtained (strain VE18944, Table S1).

\section{Results}

\subsection{Characterization of the Enterococcus Phage Idefix}

\subsubsection{Isolation, Morphological Characterization, and Phage-Host Relationship}

One municipal sewage water sample from Sèvres (Paris area, Ile de France region) was screened by direct plating without enrichment for phages forming plaques on the indicator strain. This latter, VE18590 (here below $\mathrm{pp}^{-}$, complete names of all strains used are listed in Table S1), corresponds to an E. faecalis V583 derivative deleted from its endogenous plasmids and six active prophages [43]. A phage making particularly large and clear plaques was isolated with the double-layer technique. After purification and amplification, transmission electron microscopy revealed a virion with an icosahedral head $\sim 40 \mathrm{~nm}$ in diameter and a very short non-contractile tail (Figure 1A). This phage, Idefix, therefore belongs to the Caudovirales order and the Podoviridae family. A one-step growth kinetic indicated that Idefix has a latent period of $15 \mathrm{~min}$ and a burst size $~ 50$ PFUs per infected $\mathrm{pp}^{-}$bacterium (Figure 1B).
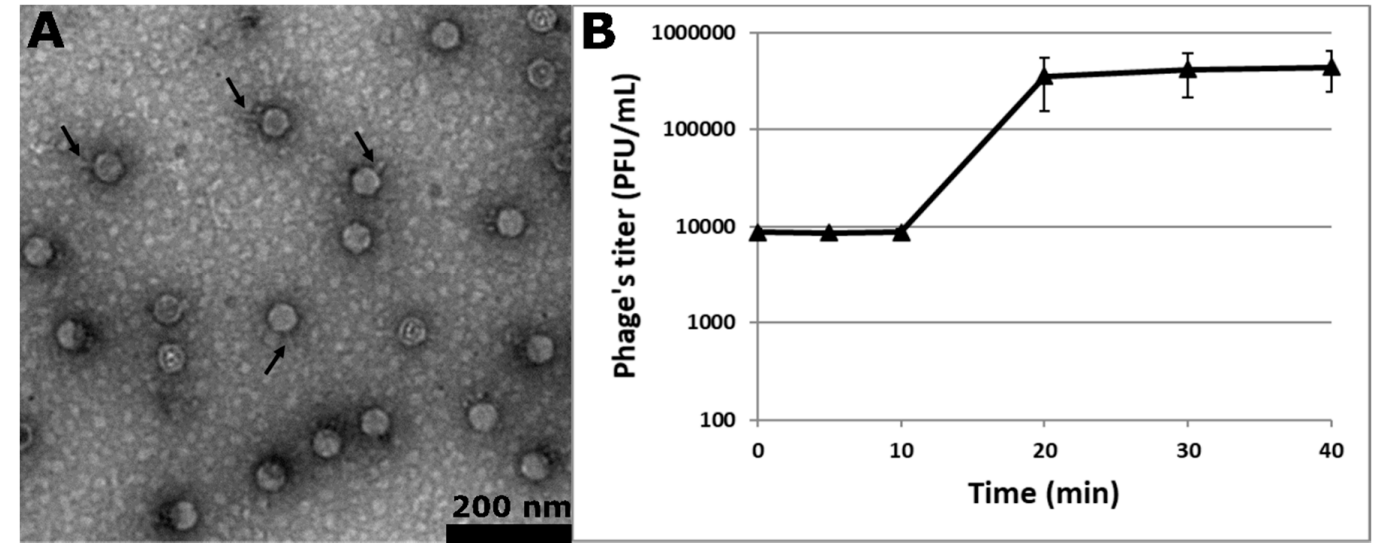

Figure 1. Characterization of the virulent phage Idefix. (A) Electron micrograph of Idefix particles negatively stained with $2 \%$ uranyl acetate (some Idefix tails are shown by arrows). (B) One step growth kinetic of phage Idefix determined in its host strain E. faecalis $\mathrm{pp}^{-}$. The values indicate the means and standard deviations of three independent experiments. 


\subsubsection{Genomic Characterization}

The genome of phage Idefix is a double stranded linear DNA, consisting of 18,168 bp with inverted terminal repeats $61 \mathrm{bp}$ long and an average GC content of $33.2 \%$. It is highly homologous to Enterococcus phages vB_EfaP_IME195 (95\% coverage and 92\% nt identity) and vB_Efae230P-4 (75\% coverage and $85 \%$ identity) (Figure 2). These genomes belong to virulent podophages, which were isolated from sewage samples in China and Poland, respectively [13,44]. A close relative phage, vB_EfaP_IME199, infecting an E. faecium strain has also been described [14]. Genbank accession numbers of these genomes are listed in Table S3.

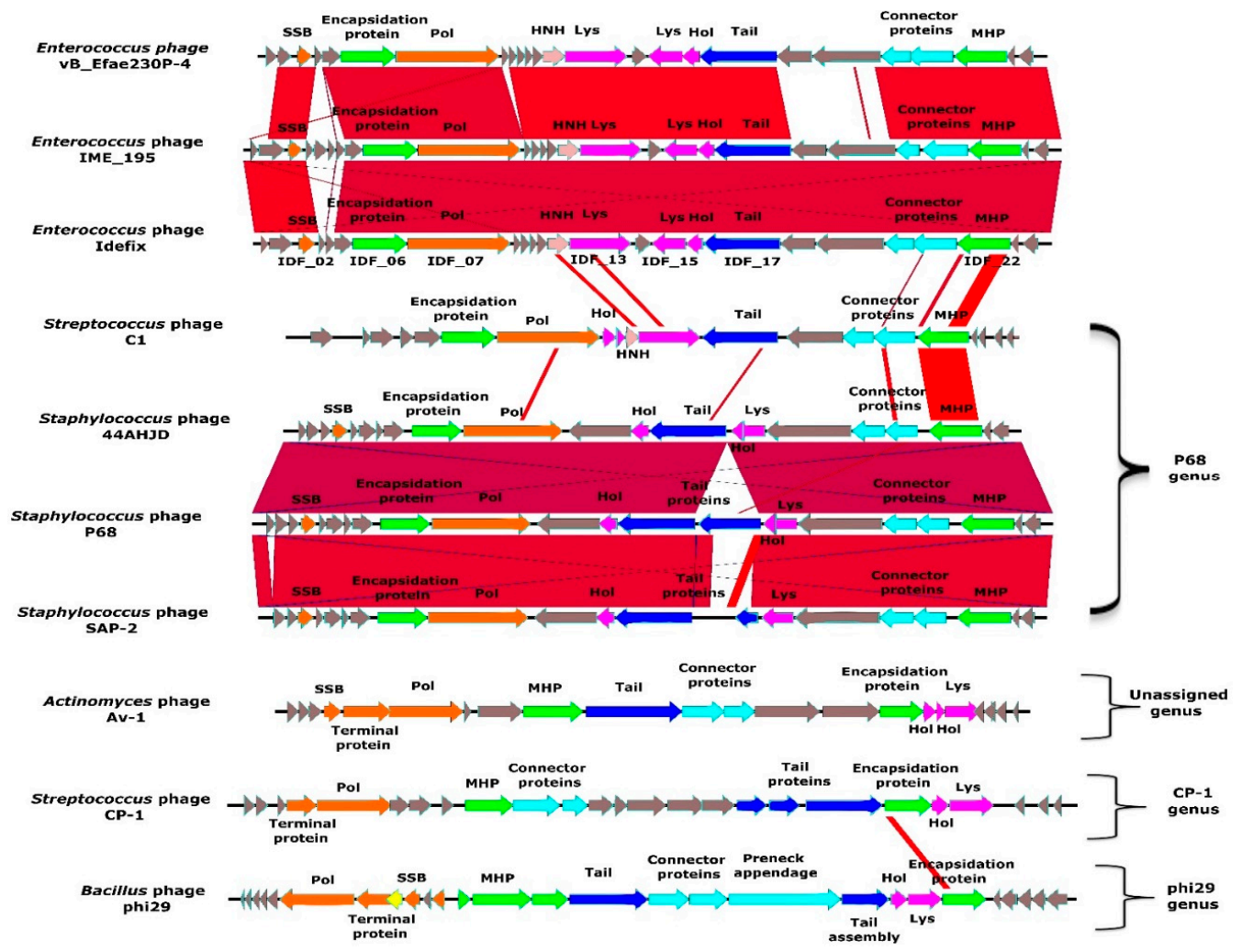

Figure 2. Annotation and comparison of the phage Idefix genome. Enterococcus phage genomes from vB_Efae230P-4, vB_EfaP_IME195, and Idefix compared to Streptococcus phage C1, Staphylococcus phages 44AHJD, P68, SAP-2, 66, Actinomyces phage Av-1, Streptococcus phage CP-1 and Bacillus phage phi29 all belonging to the Picovirinae subfamily. Gene functions are color-coded and detailed (yellow: transcriptional regulation, orange: DNA metabolism, green: DNA packaging and head, light blue: head to tail, dark blue: tail, pink: HNH endonuclease, fuchsia: lysis, grey: hypothetical proteins).

The Idefix genome encodes 25 ORFs, 12 of which were assigned a function (Figure 2 and Table S4). The replication module contains a single strand DNA binding protein (SSB, IDF_02) and a DNA polymerase belonging to the $\mathrm{B}$ type superfamily (Pol, IDF_07). This polymerase presents all the conserved motifs typical of phage phi29 polymerase, including the specific regions of the "protein priming" subfamily [67-71] (Figure S1).We next searched for the gene coding the terminal protein used to initiate the replication at both ends of Picovirinae linear genomes. Such genes are generally located near the polymerase gene but very poorly conserved. Terminal proteins share features like a small size and a high isoelectric point [72,73]. Based on these criteria, IDF_05 appears the best candidate (Table S4) but additional investigations are needed to confirm this hypothesis. A gene encoding an encapsidation protein (IDF_06) separates this putative terminal gene and the polymerase gene. The lysis module is composed of a holin (Hol, IDF_16) and two different putative endolysins (Lys): IDF_15 and IDF_13. IDF_15 displays homology with $N$-acetylmuramoyl-L-alanine amidases (Figure S2A,B). To 
test whether this gene expresses an active endolysin, IDF_15 was cloned in an expression vector based on a T7 promoter (plasmid pAB2) and expressed in E. coli ER2566 (Figure S4A). Spotting of a soluble cell extract (containing IDF_15, Figure S4A) on a pp- bacterial lawn revealed a lysis zone (Figure S4B). This result tends to show that IDF_15 has an endolysin activity. IDF_13 displays homology with PlyCA [74-76], a subunit of the PlyC endolysin synthetized by the Streptococcus podophage C1 (Figure S3A). Indeed IDF_13, like plyCA, encodes a protein with two catalytic domains. A putative glycosidase domain (homologous to the one of PlyCA) and a putative "CHAP" domain (more divergent compared with the one found in PlyCA) are respectively located in the $\mathrm{N}$ and the $\mathrm{C}$ terminus of the protein (Figure S3B,C). In contrast to IDF_15, a soluble cell extract of an E. coli strain expressing the IDF_13 (via plasmid pAB1) did not lead to a bacterial lysis (Figure S4A,B). Moreover, a mix of extracts containing IDF_13 and IDF_15 did not produce increased lysis (Figure S4B). C1 is the only reported phage whose endolysin PlyC is synthesized from two genes: plyCA and plyCB. To form the complete enzyme, the catalytic subunit PlyCA and eight subunits PlyCB harboring the cell wall binding domain (CBD) are associated $[75,77]$. However, we were not able to find an Idefix ORF displaying any significant similarity with PlyCB. We concluded that IDF_15 seems to encode a canonical monomeric endolysin, and that more experiments are required to determine whether IDF_13 is just remnant of a former endolysin module, or retains activity combined with another Idefix protein to form a multimeric endolysin. Finally, the structural module includes genes encoding a tail protein (IDF_17), connector proteins (IDF_20 and IDF_21) and a major head protein (MHP, IDF_22) (Table S4).

Comparative genomic analyses clearly show that Idefix and the other homologous Enterococcus phages belong to the Picovirinae subfamily [78] composed of small virulent podophages infecting Gram-positive bacteria and encoding a phi29-like DNA polymerase. The Picovirinae subfamily is subdivided into P68, phi29, Cp-1 genera and one unassigned genus (Figure 2). The overall synteny and the MHP similarities [14] both lead to assign Idefix and all other Enterococcus Picovirinae to the P68 genus, including one Streptococcus and some Staphylococcus phages (Figure 2). Within this genus, a hallmark of all Enterococcus phages is the presence of two genes coding putative endolysins (IDF_13 and IDF_15 in Idefix).

\subsubsection{Phage Host Range}

Plaque assays of Idefix were performed on fifty-nine Enterococcus strains, belonging to the E. faecalis (47) and to the E. faecium (12) species. E. faecalis strains had sewage, clinical, commensal, or food origins and represented a range of different clonal complexes and capsule types, whereas faecium strains essentially belonged to different sequence types from the most prevalent clinical clonal complex (Table S2). Idefix did not propagate on any of them, including the wild type strain V583 (wt), from which our indicator sensitive strain $\mathrm{pp}^{-}$is derived (Figure 3A,B).

\subsection{Characterization of E. faecalis V583 Resistance to Idefix}

\subsubsection{Novel Abi System Encoded by V583 Prophage 6}

To investigate the mechanism by which E. faecalis V583 resists Idefix infection, we made use of our collection of V583 derivatives deleted for either plasmids or prophages [43]. The plasmids hosted by V583 were not responsible for the resistance to Idefix, as the use of the plasmidless V583 derivative strain VE14089 (pp ${ }^{+}$, Table S1), did not permit Idefix growth (Figure 3C). Plaque assays were next performed on V583 plasmidless derivatives where only one of the prophages remains. Idefix grew on all derivatives (Figure 3D-H) but one, VE18581 (pp6 ${ }^{+}$) in which prophage 6 is present (Figure 3I). We concluded that prophage 6 is necessary to confer resistance to Idefix. Plaque assays on the V583 derivative VE18306 (pp6 ${ }^{-}$) in which only prophage 6 is deleted, led to clear plaque appearance (Figure 3J) with efficiency of plaquing (EOP) similar to $\mathrm{pp}^{-}$(Table 1). We concluded that prophage 6, which structural genes are notably related to the siphophage HK97, is sufficient for Idefix resistance. Interestingly, we noticed that plaque size was reduced ( $\sim$ three times smaller) whenever 
prophage 3 was present (Figure 3G,H,J) (Table 1), suggesting that prophage 3 slightly interferes during Idefix infection.

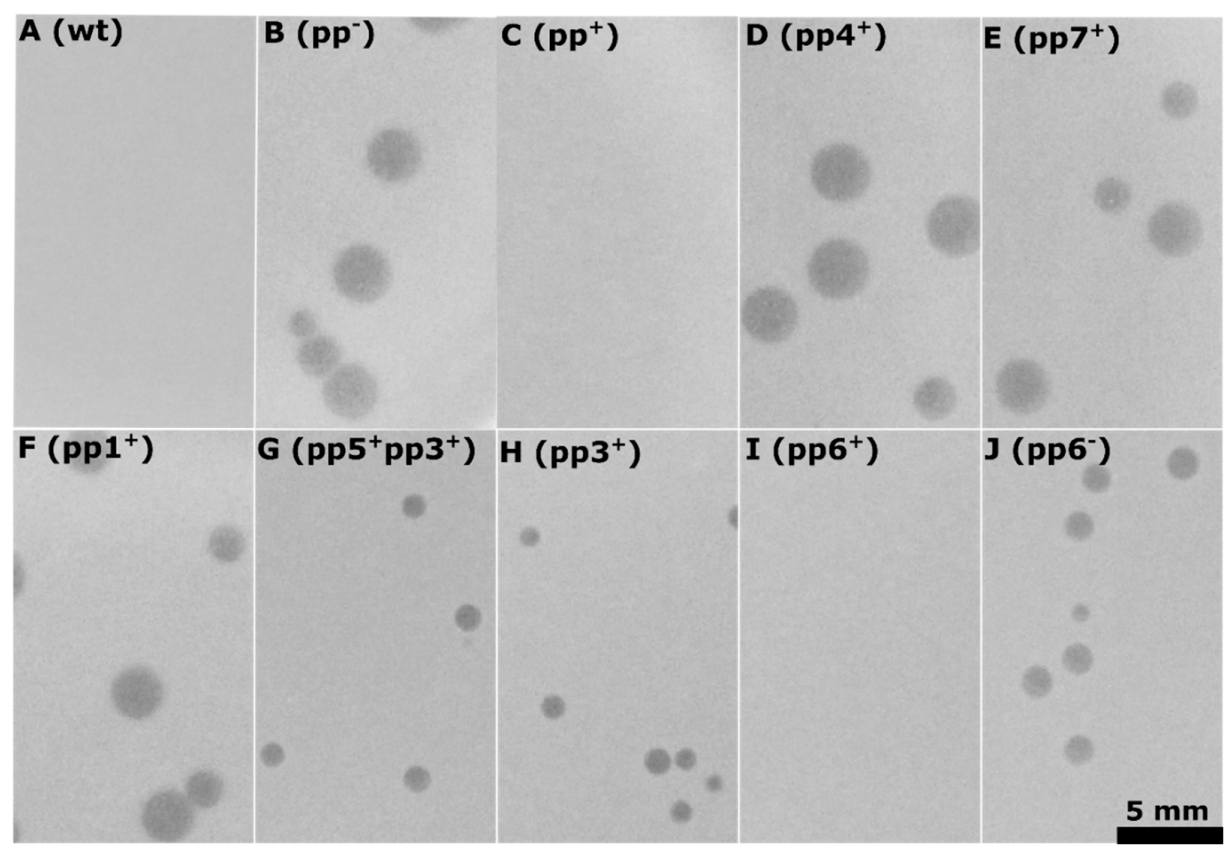

Figure 3. V583 endogenous prophages (pps) interference with Idefix infection, plaque assays performed on strains: A. wt (VE14002), V583 clinical isolate. B. pp- (VE18590), a V583 derivative deleted for all its plasmids and prophages. C. pp ${ }^{+}$(VE14089), a V583 derivative only deleted from all its plasmids. D. $\mathrm{pp}^{+}$(VE18582), a VE14089 derivative deleted for all its pps but pp4. E. pp7 $7^{+}$(VE18589), a VE14089 derivative deleted for all its pps but pp7. F. pp1 $1^{+}$(VE18562), a VE14089 derivative deleted for all its pps but pp1. G. pp3 $3^{+}$pp5 $^{+}$(VE18583), a VE14089 derivative deleted for all its pps but pp3 and pp5. H. pp3 ${ }^{+}$ (VE18584), a VE14089 derivative deleted for all its pps but pp3. I. pp6 ${ }^{+}$(VE18581), a VE14089 derivative deleted for all its pps but pp6. J. pp6 ${ }^{-}$(VE18306), a VE14089 derivative only deleted from pp6.

Table 1. Efficiency of plaquing (EOP) of phage Idefix on E. faecalis V583 derivatives deleted from different prophages.

\begin{tabular}{ccc}
\hline Strain (Genotype) & Average EOP of Idefix (sd) & Plaque (Diameter) \\
\hline VE18590 $\left(\mathrm{pp}^{-}\right)$ & 1 & Big clear plaque $(3-4 \mathrm{~mm})$ \\
VE18562 $\left(\mathrm{pp}^{+}\right)$ & $1.1(0.17)$ & Big clear plaque $(3-4 \mathrm{~mm})$ \\
VE18582 $\left(\mathrm{pp}^{+}\right)$ & $0.92(0.14)$ & Big clear plaque $(3-4 \mathrm{~mm})$ \\
VE18589 $\left(\mathrm{pp}^{+}\right)$ & $1.03(0.16)$ & Big clear plaque $(3-4 \mathrm{~mm})$ \\
VE18583 $\left(\mathrm{pp}^{+}+\mathrm{pp5}^{+}\right)$ & $0.97(0.16)$ & Reduction in size $(1 \mathrm{~mm})$ \\
VE18584 $\left(\mathrm{pp}^{+}\right)$ & $0.92(0.17)$ & Reduction in size $(1 \mathrm{~mm})$ \\
VE18581 $\left(\mathrm{pp}^{+}\right)$ & $0^{*}$ & No plaque visible \\
VE18306 $\left(\mathrm{pp}^{-}\right)$ & $1(0.13)$ & Reduction in size $(1 \mathrm{~mm})$ \\
\hline
\end{tabular}

* Below the detectable limit of the assay, at least $<1.2 \times 10^{-8}$.

To characterize the resistance conferred by prophage 6, adsorption assays were first performed on a panel of strains differing for the presence or absence of this prophage. Idefix adsorption was always efficient, regardless of the presence of prophage 6 (Table 2), showing therefore that prophage 6 does not prevent Idefix adsorption. We next assayed efficiency of center of infection (ECOI) by Idefix on the same panel of strains, which can detect infective events, regardless of phage burst size. It was reduced to $39 \%$ upon infection of strain $\mathrm{pp}^{+}$. This reduction was even more drastic when the strain $\mathrm{pp}^{+}$, carrying all prophages, was tested, with only $15 \%$ of the infections leading to phage production. This suggests again that some other prophage gene(s) impede Idefix growth. However, infection of strain $\mathrm{pp}^{-}$permitted to recover plaques for nearly $70 \%$ of all infecting particles, suggesting that prophage 
6 contribution to interference is major (Table 2). We finally tested whether prophage 6 affected cell survival upon Idefix infection. Cell survival following exposure to Idefix was similar irrespective of the presence of prophage 6: even in the Idefix resistant strains, percentage of cell death was around 50-70\% at MOI of 1 , and around $100 \%$ at MOI of 10, like in Idefix sensitive strains (Table 2). We concluded that prophage 6 encodes a typical Abi mechanism affecting the production of virions while leading simultaneously to host cell death upon Idefix infection.

Table 2. Parameters of phage Idefix proliferation on E. faecalis strains differing by the presence or absence of prophage 6 or prophage 6-encoded ef2833.

\begin{tabular}{|c|c|c|c|c|}
\hline $\begin{array}{c}\text { Strain } \\
\text { (Genotype) }\end{array}$ & $\begin{array}{c}\text { \% EOP (Plaques } \\
\text { Diameter) }\end{array}$ & \% Adsorption (sd) & $\%$ ECOI (sd) & $\begin{array}{c}\% \text { Bacterial Death at } \\
\text { MOI } 1(\mathrm{sd}) \text { and MOI } \\
10(\mathrm{sd})\end{array}$ \\
\hline $\begin{array}{l}\text { Indicator strain } \\
\text { VE18590 }\left(\mathrm{pp}^{-}\right)\end{array}$ & $100(3-4 \mathrm{~mm})$ & $96.5(1.63)$ & 100 & $69.0(0.39)$ and $99.2(0.78)$ \\
\hline VE18306 (pp6-) & $100(1 \mathrm{~mm})$ & $97.1(1.35)$ & $69.3(3.10)$ & $52.8(3.00)$ and $98.2(0.98)$ \\
\hline VE18581 $\left(\mathrm{pp}^{+}\right)$ & 0 None plaques visible & $97.5(0.92)$ & $39.5(3.94)$ & $66.8(2.78)$ and $98.2(1.32)$ \\
\hline $\operatorname{VE} 14089\left(\mathrm{pp}^{+}\right)$ & 0 None plaques visible & $98.1(2.36)$ & $15.9(4.01)$ & $60.2(3.46)$ and $98.9(0.19)$ \\
\hline VEJL3 $\left(p p 6^{-}\right.$, ef $\left.2833^{+}\right)$ & 0 None plaques visible & $98.4(0.68)$ & $9.46(2.68)$ & $67.7(1.65)$ and $98.6(0.46)$ \\
\hline VEJL5 $\left(\mathrm{pp}^{-}\right.$, ef $\left.2833^{+}\right)$ & 0 None plaques visible & $98.5(1.33)$ & $13.8(0.58)$ & $63.2(1.98)$ and $96.6(1.36)$ \\
\hline
\end{tabular}

To search for prophage 6 candidate genes involved in this Abi mechanism, we analyzed transcriptomic data of strain $\mathrm{pp}^{+}$[48]. Eight of the prophage 6 encoded genes are expressed constitutively during normal growth conditions, in contrast to the generally low expression level of the remaining 50 genes carried by the prophage (Figure 4A). Two of these genes, ef2855 and ef2852, encode the integrase and repressor proteins, which are implicated in the lysogenic control of the prophage. Between these two genes, and probably forming an operon with them, genes ef 2854 and ef2853 encode a putative membrane protein and a putative metallo-peptidase, respectively. A similar gene pair, placed between an integrase and a repressor, is found in several Sie prophage-encoded phage resistance systems within the Lactococcus genus $[37,79]$. These systems block the phage DNA injection step, due to the membrane protein. The nearby metallo-peptidase is dispensable, but sometimes enhances the resistance efficiency [37,79]. Given that Sie systems do not affect bacterial survival, we did not consider the gene pair ef 2853 and ef 2854 as responsible for the observed resistance to Idefix infection. Among the four last candidate genes, ef 2801 is disrupted by a transposable element invalidating a putative glycosyltransferase, so that our investigation was restricted to the three remaining genes ef2833, ef 2847 , and ef2850.

All of them are preceded by a promoter region including an experimentally mapped transcription-starting site [80] and encode proteins with unknown function. We thus cloned these three genes individually with their own promoters on pJIM2246 vector (Table S1), and performed Idefix infections in pp6 ${ }^{-}$transformed by each of the plasmids. Plaque assays revealed that Idefix was able to infect all strains (Figure $4 \mathrm{~B}(\mathrm{a}, \mathrm{b})$ but the one hosting plasmid pJL3, in which ef2833 is expressed (Figure 4B(c)). We additionally tested plasmid pJL3 in the $\mathrm{pp}^{-}$background and found that this strain was also resistant to Idefix (Figure $4 \mathrm{~B}(\mathrm{~d})$ ) whereas the phage grew on the isogenic strain hosting the empty vector (Figure $4 \mathrm{~B}(\mathrm{e}))$ as well as on $\mathrm{pp}^{-}$(Figure $4 \mathrm{~B}(\mathrm{f})$ ). 
A

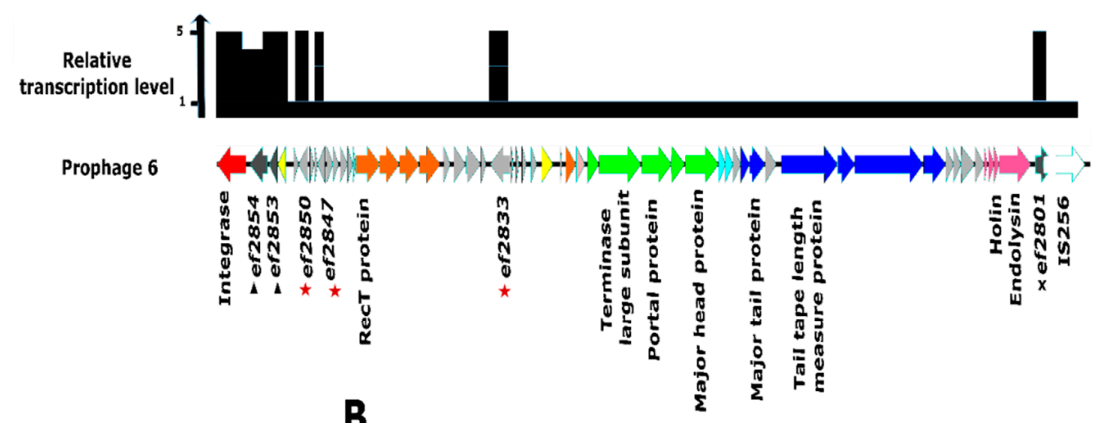

B

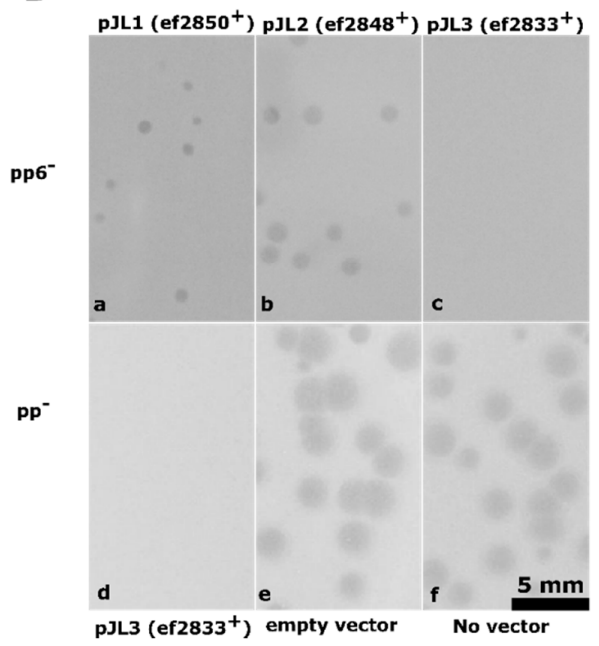

Figure 4. Identification of the V583 endogenous prophage 6 (pp6) gene responsible for Idefix resistance. (A) Genomic organization of pp6 and relative transcription level of each gene. The genomic organization of pp6 is modified from [43]. Gene functions are color-coded and detailed wherever possible (red: integrase, yellow: transcriptional regulation, orange: DNA metabolism, green: DNA packaging and head, light blue: head to tail, dark blue: tail, fuchsia: lysis, grey: hypothetical proteins, white: transposable element). Relative transcriptional level of each gene is indicated in black and designed from a previously published transcriptomic study [48]. Eight pp6 genes are constitutively expressed during V583 normal growth conditions. Among those not involved in pp6 lysogenic decision: a membrane protein and putative metallo-peptidase genes are indicated with triangles, a putative glycosyltransferase gene disrupted by a transposable element is indicated with a cross and the three other genes tested as abi candidates are indicated with red stars. (B) Interference with Idefix infection following the expression of the three pp6 abi candidates, plaque assays performed on strain pp6 ${ }^{-}$(A to C) or $\mathrm{pp}^{-}$(D to F) transformed by: a. pJL1. b. pJL2. c. pJL3. d. pJL3. e. the pJIM2246 empty vector. f. no vector.

We then checked the other proliferation parameters of Idefix on the two strains hosting the pJL3 plasmid. The phage adsorbed as efficiently on these strains, its ECOI was reduced to $\sim 10 \%$ and the percentage of cell death were around $60-70 \%$ at MOI 1 and around $100 \%$ at MOI 10 in both cases (Table 2). These results confirmed that ef2833 is responsible for the abortive mechanism. As letters from $a b i A$ to abiZ have been used once to designate over 20 L. lactis Abi systems [18,81], we renamed ef 2833 as "abi $\alpha$ ". The corresponding encoded protein contains 272 residues, and does not exhibit similarity with any domain or protein of known function. Abi $\alpha$ nevertheless constitutes a PFAM domain referred to as DUF4393 (158 sequences, 140 species, both $\mathrm{Gram}^{+}$and $\mathrm{Gram}^{-}$), suggesting already its broad distribution (see below). Abi $\alpha$ also shares similarity with Pfam entry PF10987 and PDB entry 3H35 without providing any substantial information about Abi $\alpha$ function.

To characterize the Abi $\alpha$ mode of action, lysis curves were conducted and indicated that strain $\mathrm{pp}^{-}$containing plasmid pJL3 lyses $\sim 10$ min earlier than its isogenic strain devoid of $a b i \alpha$ after infection 
by Idefix (MOI 10) (Figure 5A). The same results were obtained when comparing lysis curves of the prophage positive and prophageless strains $\mathrm{pp}^{+}$and $\mathrm{pp}^{-}$, respectively (Figure 5B). We concluded that Abi $\alpha$ provokes a lysis asynchrony.

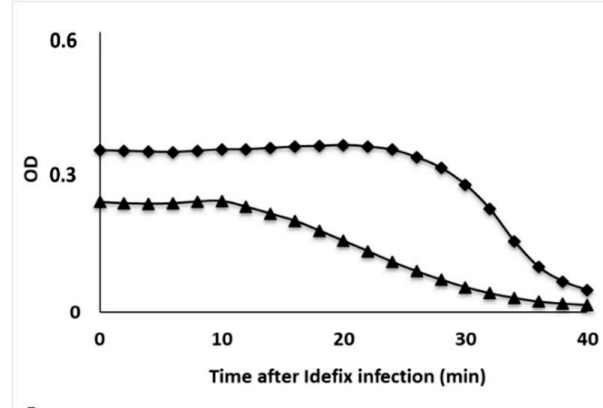

A
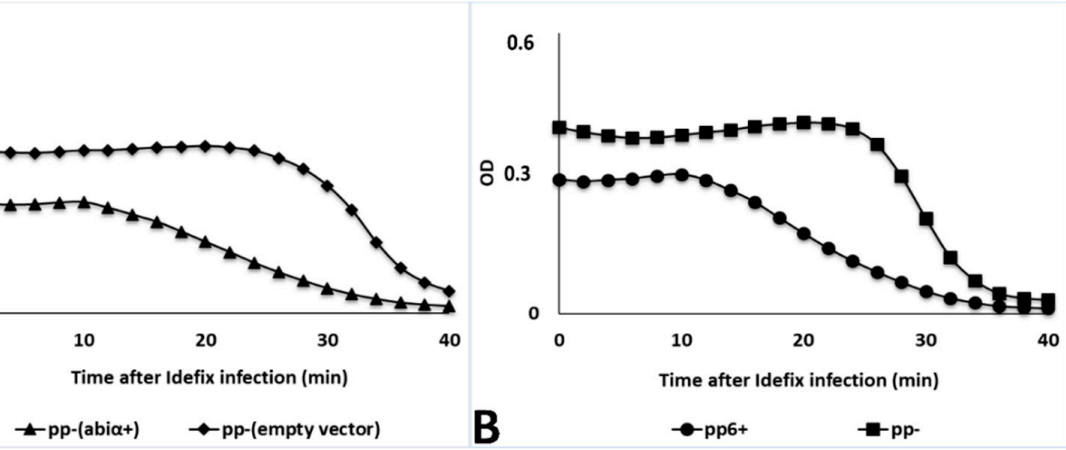

B

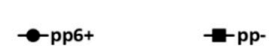

Figure 5. Lysis curves after Idefix infection at MOI 10. (A) Comparison between pp ${ }^{-}$pJIM2246abi $\alpha^{+}$ (VEJL5) and pp $^{-}$pJIM2246 (VEJL4) in triangles and diamonds, respectively. (B) Comparison between $\mathrm{pp}^{+}$and $\mathrm{pp}^{-}$in circles and squares, respectively. The results shown are representative of three biological replicates (see Figure S5).

To evaluate the prevalence of $a b i \alpha$ and its genetic context, the protein sequence was searched in the JGI database with the IMG interface ([82]; BLASTP, E-value $<3.10^{-8}$, Identity $\geq 25 \%$ ). Homologs of Abi $\alpha$ were found mostly on prophages, with some of them shown in Figure S6: the closer relatives (61-59\% sequence identity) came from various enterococci, such as E. faecium and Enterococcus villorum isolates, and subsequent analyses with the NCBI nt database also revealed a homolog in an Enterococcus hirae prophage (not shown in Figure S6). Other Abi $\alpha$ were found in about 50 Lactobacillus strains (27-42\% sequence identity). Roughly, half of these genes are encoded on prophages (as in L. johnsonii, L. salivarius or L. plantarum isolates) whereas the other half are located on the chromosomes (as in L. lindneri and L. helveticus isolates). Interestingly, in L. helveticus, and in two Oenococcus species (O. kitaharae and O. oeni), the abia gene is close to other putative Abi systems, and may belong to a phage resistance island. Sporadic occurrences (31-37\% sequence identity) were also found in three Streptococcus species (S. suis, S. bovis, and S. parasanguinis), and one Carnobacterium isolate. A prophage context was detectable in this latter and in S. parasanguinis. Additional prophage-encoded genes with $25-27 \%$ sequence identity with abia were located in one Lactococcus lactis ssp. lactis (not shown in Figure S6), Bacillus velezensis, Staphylococcus epidermidis, Staphylococcus scuiri and Staphylococcus aureus. We conclude that Abi $\alpha$ is widely distributed, and hypothesize it has a phage origin.

\subsubsection{Mutagenesis in V583 epa Variable Region as Potential Additional Line of Defense}

During this work, we regularly observed phage-resistant colonies growing within lysis zones of the $\mathrm{pp}^{-}$strain. Fluctuation tests of Luria-Delbrück allowed estimating that the frequency of mutations resulting in resistance of the strain was $1.56( \pm 0.54) \times 10^{-4}$ per cellular division. We conclude that spontaneous resistance to Idefix arises at high frequency in E. faecalis strain devoid of abix.

To gain further insights into the bacterial mechanisms of resistance to Idefix, we tested nine spontaneous Idefix resistant mutants randomly isolated from fluctuation tests. Idefix adsorption was reduced for all mutants: three of them had a 2-to-4-fold reduced adsorption efficiency and the remaining six, rather a 10-fold defect (Table S5). We conclude that bacterial resistance to Idefix is due to an adsorption defect.

More than 10 years ago, a study of the podophage $\mathrm{C} 1$ distantly related to Idefix (see Figure 2) had proposed that the $\mathrm{N}$-acetylgalactosamine (GalNac) composing the side chains of the group C streptococci surface rhamnopolysaccharide should be a crucial element of the bacterial receptor [83]. Enterococci, like group C streptococci, harbor a surface rhamnopolysaccharide or Epa (Enterococcal polysaccharide antigen), which is synthesized by more than thirty proteins encoded within a single 
cluster of genes. The upstream part of this gene cluster is shared among E. faecalis strains, while the immediately downstream region is variable between strains [84]. Within this epa variable region, epaX encodes a glycosyltransferase involved in the incorporation of galactose and/or GalNac proposed to form the side chains of the rhamnopolysaccharide in E. faecalis [49]. We therefore started by examining the epaX region in the nine mutants. PCR amplification of epaX led to a DNA product of increased size in six out of nine mutants ( $\sim 4000$ instead of $\sim 2500 \mathrm{bp}$ ). Sequencing revealed that epaX gene was disrupted by an IS256 insertion sequence, positioned in either direction, and at six different locations, all of them in the very distal 3' region of epaX (Figure 6 and Table S5).

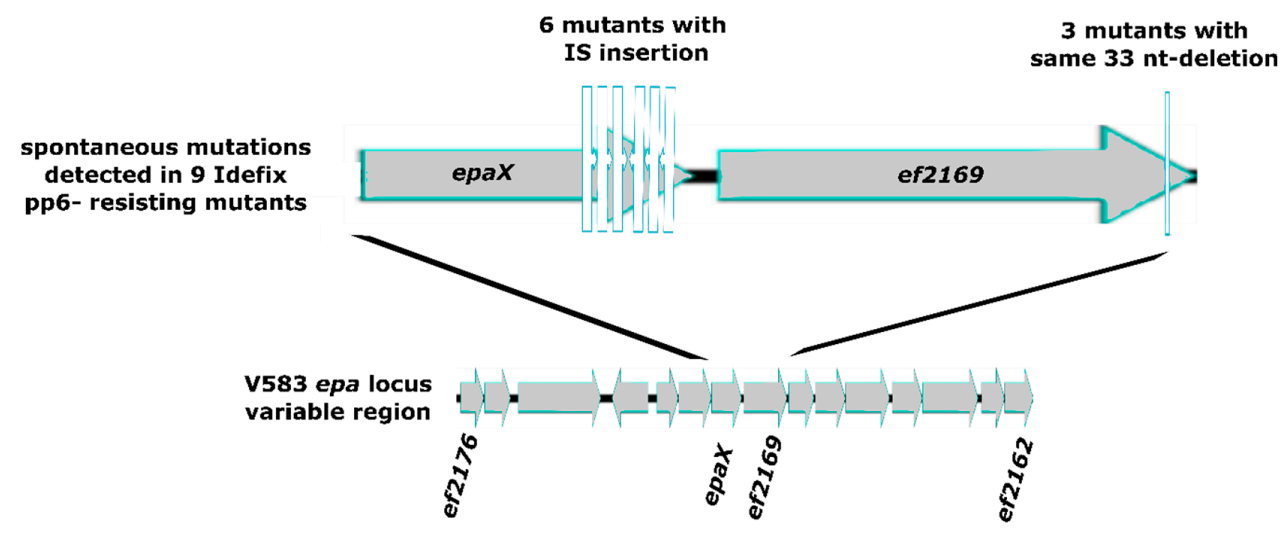

Figure 6. Genomic organization of V583 variable epa locus and focus on spontaneous mutations found in epaX region for nine Idefix $\mathrm{pp}^{-}$resisting mutants.

We next reconstructed a deletion of epaX in the $\mathrm{pp}^{-}$background. Again, Idefix was almost unable to adsorb to the resulting strain (VE18393, Table S1) with only $5 \%( \pm 8)$ of adsorption, nor to lyse it (Figure 7A). Complementation of this epaX mutant with plasmid pVE14176 expressing constitutively epaX under a strong promoter (strain VE18945, Table S1) restored Idefix adsorption, which reached 96\% $( \pm 2)$, as well as the capacity of plaquing (Figure 7B). Results on the isogenic strain (VE18944, Table S1) hosting the empty vector were $5 \%( \pm 6)$ of phage adsorption and no plaque formation (Figure 7C). We concluded that epaX is required for Idefix adsorption.

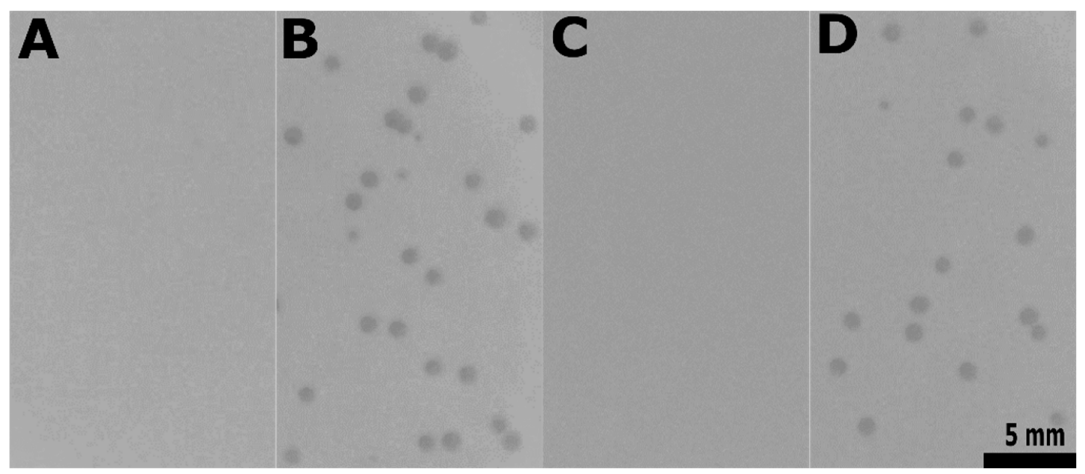

Figure 7. epaX gene expression is required for Idefix infection of $\mathrm{pp6}^{-}$. Plaque assays performed on strains: (A) pp6 ${ }^{-}$epaX ${ }^{-}$(VE18393), a VE18306 derivative deleted from epaX. (B) $\mathrm{pp6}^{-}$epaX ${ }^{-} \mathrm{pVE14176epaX}^{+}$(VE18945), a VE18393 derivative complemented with epaX. (C) pp6 $^{-}$epaX ${ }^{-}$pVE14176 (VE18944), a VE18393 derivative carrying the empty vector. (D) pp6 ${ }^{-}$(VE18306), a V583 derivative deleted from its plasmids and pp6.

To characterize the three remaining Idefix-resistant mutants, in which no IS was detected in the epaX region by PCR, we sequenced the genome of one of them, and mapped the reads against the pp6 ${ }^{-}$ reference genome. We identified a 33 nt-long deletion, flanked by $11 \mathrm{nt}$-long direct repeats, within ORF ef2169 encoding a predicted $\mathrm{O}$ antigen polymerase, and located immediately downstream of epaX. 
PCR amplification and sequencing of ef 2169 gene in the two last mutants allowed to detect the same $33 \mathrm{nt}$ deletion in both of them (Figure 6 and Table S5). The observed deletion results in an in-frame 11 amino acids deletion in the $\mathrm{C}$-terminal region of the putative $\mathrm{O}$ antigen polymerase. Additional single nucleotide polymorphisms (introducing amino acid substitution and a premature stop codon, respectively) were also observed in these two last ef2169 mutants (Table S5). Complementation of the ef 2169 mutation could not be checked, due to our failure to clone the ef 2169 gene on a plasmid, despite repeated attempts in E coli, L. lactis, and E. faecalis.

\section{Discussion}

Enterococci are particularly successful at rapidly acquiring resistance to virtually any antibiotic used in therapy, with vancomycin-resistant enterococci (VRE) being a major clinical problem. If phage therapy is consequently nowadays (re)considered as an alternative to combat VRE infections, we are still nowhere near using enterococci phages as therapeutic agents in routine. Before that, we need to better characterize (i) enterococci phage receptors that define phage strain specificity, and (ii) enterococci resistance mechanisms that constitute the major constraint of phage therapy $[7,16]$.

The present study with the new virulent podophage, Idefix, fulfills these goals. The phage was isolated by using the reference vancomycin-resistant E. faecalis V583 clinical isolate, deleted from its endogenous plasmids and prophages, as a recipient for phage infections. Idefix belongs to the Picovirinae subfamily and P68 genus and is closely related to three phages recently isolated on E. faecalis [13,44] or E. faecium [14]. They encode a DNA polymerase from the B type superfamily, which is a hallmark of the Picovirinae. As an additional hallmark of these enterococci podophages, they all encode two types of predicted endolysins. Endolysin engineering has emerged as a suitable strategy for food safety, environment decontamination, and infections control [85]. Some of the characterized enterococci phage endolysins show potential to combat VRE in vivo $[15,86]$ and could represent an alternative to resolve the VRE problem. Idefix both encodes endolysin IDF_15, a predicted $\mathrm{N}$-acetylmuramoyl-L-alanine amidase for which we could presume activity by spot assays on bacterial lawns, and IDF_13, similar to the catalytic subunit of the endolysin PlyC encoded by Streptococcus phage $\mathrm{C} 1$, which was inactive in the same spot assay. PlyC is the unique example of multimeric endolysin and represents the more active peptidoglycan hydrolase reported to date [85]. We were unable to identify by similarity an Idefix gene that could encode the CBD of this complex, and allow the formation of a putative multimeric endolysin. CBD of endolysins bind to specific substrates on the bacterial surfaces, often giving rise to near-species-specific binding, so that endolysins of the same class often share very little sequence similarity in the binding region [85]. Identification of the CBD subunit homolog in Idefix and complete characterization of this intriguing endolysin requires further investigation.

Idefix was unable to lyse any of our fifty-nine strains of E. faecalis and E. faecium, suggesting it could originate from another enterococcal species. Plaques were obtained against the indicator strain used for its isolation, and not on the wild type isolate V583 from which the indicator strain is derived. This apparently narrow host range could be explained by the reported Abi $\alpha$-sensitivity and perhaps more importantly by the receptor-specificity of Idefix.

In V583, resistance to the phage was mainly due to the gene abia (formerly ef2833) encoded by prophage 6. Upon Idefix infection, cells are dying while the Idefix lytic cycle is perturbed (ECOI of $\sim 40 \%$ and $\sim 10 \%$ whenever abia is expressed on prophage 6 or overexpressed on cloning vectors, respectively) so that its efficiency of plaquing is below $10^{-8}$ and the detectable limits of the assay for Idefix. To our knowledge, it is the first time that an Abi system is described within enterococci, and the first one targeting a Picovirinae. This new Abi protein is widely distributed, it corresponds to the PFAM DUF 4393, and we report here that it is mostly found in prophages, arguing that it is essentially a temperate phage weapon to fight against other phages. Abi are specific anti-phage defence mechanisms present in many bacterial species including Shigella dysenteriae, Streptococcus pyogenes, Vibrio cholerae, Bacillus subtilis, and Bacillus licheniformis [62,87-90]. They have been more extensively 
studied in L. lactis and E. coli $[17,81]$. Most abi genes are encoded by a single gene on mobile genetic elements (MGE), on prophages in E. coli [91], or plasmids in L. lactis [81]. The fact that most abi genes are plasmidic in L. lactis may result however from a bias of human selection for plasmid-encoded systems in the dairy industry. Abi actually include a large collection of diverse mechanisms acting at any stage of the phage development to decrease or completely block virion production and cause host cell death. All these mechanisms display little or no known evolutionary relationship, apart from a very similar phenotype [18,81,92].

Lysis curve experiments show that the expression of abia triggers a premature lysis of Idefix-infected E. faecalis. A similar phenotype was described in L. lactis, in which lysis, upon infection by siphophages from the P335 group, occurs earlier in the presence of AbiZ [93]. AbiZ speeds up the lysis of L. lactis bacteria in which the phage holin and endolysin are expressed, and enhances membrane permeability of bacteria expressing the phage holin. Durmaz and Klaenhammer propose that AbiZ interacts with phage holin to accelerate the lysis clock and prevent normal phage multiplication [93]. Abi $\alpha$ and AbiZ do not share any sequence similarity. We were unable to obtain Idefix mutants that were resistant to Abi $\alpha$, suggesting a very high efficiency of this Abi system. Based on our results, we can only speculate that Abi $\alpha$ interferes with lysis, possibly by preventing timely holin and consequently endolysin(s) actions, as described for AbiZ. Another possibility is that Abi $\alpha$ targets a putative Idefix holin inhibitor. The holin triggering, which is determinant for optimal burst size, is critically regulated by the expressed ratio between the holin and its inhibitor. This latter is encoded within the lambda holin gene, as a separate transcript initiated at a dual-start motif [94,95]. Unlike lambda (and phi29), the Idefix holin gene does not harbor a dual-start motif and its regulation may be mediated by the expression of another non-identified Idefix gene, as described in other phages [94,95]. Finally, premature triggering of lambda holin can also be induced by any poison that efficiently reduces the proton-motrice force (pmf) of the cytoplasmic membrane [94,95]. Thus, we cannot exclude Abi $\alpha$ causes a holin-independent reduction of the pmf underlying an early trigger of the holin and/or a permeabilization of the membrane leading to endolysin release. If this is the case, you might imagine that Abi $\alpha$ could be active against a wider range of phages and not only Idefix or related phages. Further experiments will be needed to test these different hypotheses and complete the characterization of this defence mechanism.

Genomes of V583 and other MDR E. faecalis isolates have few generalist anti-MGE systems, which favor horizontal gene transfer and polylysogeny [29]. MDR enterococci may thus provide a suitable ground for bacteriophages confrontation. Whereas the spread of Idefix infection is thus limited by V583 prophage 6, it is interesting to note this latter is itself strictly controlled by V583 prophages 3 and 5 that block its excision [43]. This 'domestication' could be seen as a way for both prophages to sustain the specific line of defense conferred by prophage 6 and thus protect themselves and their host from an external phage 'attack'.

Beyond the intra-bacteriophage warfare, bacteria are also able to evolve resistance to phages. We observed that $E$. faecalis mutants resisting to Idefix infection arose at a high frequency of $1.5 \times 10^{-4}$ per generation. The nine Idefix-resistant mutants analyzed had either acquired an IS256 or recombined between eleven base paires long direct repeats in the epa variable region, indicating that $E$. faecalis has a high potential for evolution by recombination. Mutants in glycosyltransferase gene epaX had a 10-fold defect in Idefix adsorption, whereas mutants in the next o-polymerase gene had a milder adsorption defect. The fact that all mutations cluster into two genes of the epa variable region underlines the role of the rhamnopolysaccharide for Idefix adsorption. Epa was recently confirmed as a receptor of E. faecalis virulent phage NPV1 [96,97], and we provide here the first evidence for a role of Epa decoration chains in phage/host recognition in enterococci. Rhamnose-rich cell wall polysaccharides (CWPS) and their structural diversity are important in phage adsorption within lactococci and streptococci $[98,99]$. In L. lactis as well, CWPS biosynthesis is encoded on a large chromosomal gene cluster also including a conserved and a variable region. Based on sequence similarity and difference in the variable region, L. lactis strains were divided into three groups, and one of them in several subtypes [100]. These 
latter are distinguished by their glycosyltransferase-encoding genes composition and consequent differences between CWPS structures are critical in determining phage sensitivity [100]. The use of unconserved sugar decorations of the saccharidic chains as a receptor combined with the presence of a prophage-encoded Abi system targeting Idefix may explain Idefix very low success in E. faecalis.

\section{Conclusions}

This study of the Enterococcus infecting Picovirinae Idefix permitted to unveil two resistance mechanisms against it, one bacterial and the other viral. Bacterial mutations suppressed the Epa decoration needed for phage adsorption, and the prophage-encoded product Abi $\alpha$ interfered with Idefix timing of lysis. However, the bacterial line of defence is likely to be counterselected in vivo as V583 epaX mutants have a defect in mouse gut colonization [49]. In fact, phage selective pressure might be one of the actors of the observed diversification of the epa locus in enterococci. The viral line of defence based on Abi $\alpha$ is likely to be more robust, given that no escape mutant could be isolated. Indeed, Abi $\alpha$ is widespread both in enterococci and in Firmicutes and it may allow to fight against Picovirinae or other ranges of phages. Somehow, the different families of phages infecting the same bacterial species are in competition, so that their host resembles a battlefield. It is especially true if bacteria are devoid of generalist defense systems, as MDR E. faecalis strains tend to be. In this context, it might be expected that Abi and other specific defensive systems pave prophage genomes, allowing temperate phages to align their strategy with their host, and fight against virulent phage invaders.

Supplementary Materials: The following are available online at http:/ /www.mdpi.com/1999-4915/11/1/48/s1, Figure S1: Structural and functional map of family of B phage DNA polymerases belonging to the "protein priming" subfamily. Figure S2: IDF_15 alignments. Figure S3: Alignments of IDF_13. Figure S4: Activities of $E$. coli extracts containing putative Idefix endolysins (IDF_15 and IDF_13). Figure S5: Biological replicates relative to lysis curves experiments after Idefix infection at MOI 10. Figure S6: Putative abia homologs identified on several prophages of Gram-positive bacteria. Table S1: Bacterial strains, plasmids, and oligonucleotide primers used. Table S2: Description of Enterococcus isolates tested as potential Idefix hosts. Table S3: Respective genome accession numbers of the Enterococcus Picovirinae phages. Table S4: Features of Idefix ORFs and predicted functions of their products. Table S5: Spontaneous mutation in epaX (ef2170) or ef2169 in pp6 ${ }^{-}$and resistance to Idefix infection.

Author Contributions: Conceptualization, J.L., F.L., P.S., and M.-A.P.; Investigation, J.L., Ar.B., E.M., S.F., As.B., O.S., M.L., M.D., and F.L.; Supervision, M.-A.P.; Writing-original draft, J.L., F.L., P.S., and M.-A.P.; Writing-review \& editing, J.L.

Acknowledgments: We thank Marianne De Paepe and Lionel Rigottier-Gois for their help during this study; Christine Longin from the MIMA2 facilities (UMR 1313 GABI, INRA) for the TEM observations; Laurent Debarbieux and Sylwia Bloch, Alicja Wegrzyn as well as Vincent Cattoir who respectively provided sewage water samples and enterococci isolates.

Conflicts of Interest: The authors declare no conflict of interest.

\section{References}

1. Lebreton, F.; Willems, R.J.; Gilmore, M.S. Enterococcus diversity, origins in nature, and gut colonization. In Enterococci from Commensals to Leading Causes of Drug Resistant Infection; Gilmore, M.S., Clewell, D.B., Ike, Y., Shankar, N., Eds.; Massachusetts Eye and Ear Infirmary: Boston, MA, USA, 2014; pp. 3-46.

2. Higuita, N.I.A.; Huycke, M.M. Enterococcal disease, epidemiology, and implications for treatment. In Enterococci from Commensals to Leading Causes of Drug Resistant Infection; Gilmore, M.S., Clewell, D.B., Ike, Y., Shankar, N., Eds.; Massachusetts Eye and Ear Infirmary: Boston, MA, USA, 2014; pp. 47-72.

3. Kristich, C.J.; Rice, L.B.; Arias, C.A. Enterococcal infection-Treatment and antibiotic resistance. In Enterococci from Commensals to Leading Causes of Drug Resistant Infection; Gilmore, M.S., Clewell, D.B., Ike, Y., Shankar, N., Eds.; Massachusetts Eye and Ear Infirmary: Boston, MA, USA, 2014; pp. 89-134.

4. Sulakvelidze, A.; Alavidze, Z.; Morris, J.G. Bacteriophage therapy. Antimicrob. Agents Chemother. 2001, 45, 649-659. [CrossRef] [PubMed]

5. Cheng, M.; Liang, J.; Zhang, Y.; Hu, L.; Gong, P.; Cai, R.; Zhang, L.; Zhang, H.; Ge, J.; Ji, Y.; et al. The bacteriophage EF-P29 efficiently protects against lethal vancomycin-resistant Enterococcus faecalis and alleviates gut microbiota imbalance in a murine bacteremia model. Front. Microbiol. 2017, 8, 837. [CrossRef] 
6. Cheng, S.; Xing, S.; Zhang, X.; Pei, G.; An, X.; Mi, Z.; Huang, Y.; Tong, Y. Complete genome sequence of a new Enterococcus faecalis bacteriophage, vB_EfaS_IME197. Genome Announc. 2016, 4, e00827-16. [CrossRef] [PubMed]

7. Duerkop, B.A.; Palmer, K.L.; Horsburgh, M.J. Enterococcal bacteriophages and genome defense. In Enterococci from Commensals to Leading Causes of Drug Resistant Infection; Gilmore, M.S., Clewell, D.B., Ike, Y., Shankar, N., Eds.; Massachusetts Eye and Ear Infirmary: Boston, MA, USA, 2014; pp. 309-336.

8. Gelman, D.; Beyth, S.; Lerer, V.; Adler, K.; Poradosu-Cohen, R.; Coppenhagen-Glazer, S.; Hazan, R. Combined bacteriophages and antibiotics as an efficient therapy against VRE Enterococcus faecalis in a mouse model. Res. Microbiol. 2018, 169, 531-539. [CrossRef]

9. Gong, P.; Cheng, M.; Li, X.; Jiang, H.; Yu, C.; Kahaer, N.; Li, J.; Zhang, L.; Xia, F.; Hu, L.; et al. Characterization of Enterococcus faecium bacteriophage IME-EFm5 and its endolysin LysEFm5. Virology 2016, 492, 11-20. [CrossRef]

10. Khalifa, L.; Brosh, Y.; Gelman, D.; Coppenhagen-Glazer, S.; Beyth, S.; Poraduso-Cohen, R.; Que, Y.-A.; Beyth, N.; Hazan, R. Targeting Enterococcus faecalis biofilm using phage therapy. Appl. Environ. Microbiol. 2015, 81, 2696-2705. [CrossRef] [PubMed]

11. Khalifa, L.; Gelman, D.; Shlezinger, M.; Dessal, A.L.; Coppenhagen-Glazer, S.; Beyth, N.; Hazan, R. Defeating antibiotic-and phage-resistant Enterococcus faecalis using a phage cocktail in vitro and in a clot model. Front. Microbiol. 2018, 9, 326. [CrossRef]

12. Rahmat Ullah, S.; Andleeb, S.; Raza, T.; Jamal, M.; Mehmood, K. Effectiveness of a lytic Phage SRG1 against vancomycin-resistant Enterococcus faecalis in compost and soil. Biomed. Res. Int. 2017, 2017. [CrossRef]

13. Wang, R.; Xing, S.; Zhao, F.; Li, P.; Mi, Z.; Shi, T.; Liu, H.; Tong, Y. Characterization and genome analysis of novel phage vB_EfaP_IME195 infecting Enterococcus faecalis. Virus Genes 2018, 54, 804-811. [CrossRef]

14. Xing, S.; Zhang, X.; Sun, Q.; Wang, J.; Mi, Z.; Pei, G.; Huang, Y.; An, X.; Fu, K.; Zhou, L.; et al. Complete genome sequence of a novel, virulent Ahjdlikevirus bacteriophage that infects Enterococcus faecium. Arch.Virol. 2017, 162, 3843-3847. [CrossRef]

15. Zhang, W.; Mi, Z.; Yin, X.; Fan, H.; An, X.; Zhang, Z.; Chen, J.; Tong, Y. Characterization of Enterococcus faecalis phage IME-EF1 and its endolysin. PLoS ONE 2013, 8, e80435. [CrossRef] [PubMed]

16. Duerkop, B.A.; Huo, W.; Bhardwaj, P.; Palmer, K.L.; Hooper, L.V. molecular basis for lytic bacteriophage resistance in enterococci. MBio 2016, 7. [CrossRef] [PubMed]

17. Labrie, S.J.; Samson, J.E.; Moineau, S. Bacteriophage resistance mechanisms. Nat. Rev. Microbiol. 2010, 8, 317-327. [CrossRef] [PubMed]

18. Seed, K.D. Battling Phages: How bacteria defend against viral attack. PLoS Pathog. 2015, 11, e1004847. [CrossRef] [PubMed]

19. Goldfarb, T.; Sberro, H.; Weinstock, E.; Cohen, O.; Doron, S.; Charpak-Amikam, Y.; Afik, S.; Ofir, G.; Sorek, R. BREX is a novel phage resistance system widespread in microbial genomes. EMBO J. 2014, 34, 169-183. [CrossRef]

20. Doron, S.; Melamed, S.; Ofir, G.; Leavitt, A.; Lopatina, A.; Keren, M.; Amitai, G.; Sorek, R. Systematic discovery of antiphage defense systems in the microbial pangenome. Science 2018, 359, eaar4120. [CrossRef]

21. Depardieu, F.; Didier, J.-P.; Bernheim, A.; Sherlock, A.; Molina, H.; Duclos, B.; Bikard, D. A eukaryotic-like serine/threonine kinase protects staphylococci against phages. Cell Host Microbe 2016, 20, 471-481. [CrossRef]

22. Ofir, G.; Melamed, S.; Sberro, H.; Mukamel, Z.; Silverman, S.; Yaakov, G.; Doron, S.; Sorek, R. DISARM is a widespread bacterial defence system with broad anti-phage activities. Nat. Microbiol. 2018, 3, 90-98. [CrossRef]

23. Kronheim, S.; Daniel-Ivad, M.; Duan, Z.; Hwang, S.; Wong, A.I.; Mantel, I.; Nodwell, J.R.; Maxwell, K.L. A chemical defence against phage infection. Nature 2018, 564, 283-286. [CrossRef]

24. Burley, K.M.; Sedgley, C.M. CRISPR-Cas, a prokaryotic adaptive immune system, in endodontic, oral, and multidrug-resistant hospital-acquired Enterococcus faecalis. J. Endod. 2012, 38, 1511-1515. [CrossRef]

25. Hullahalli, K.; Rodrigues, M.; Schmidt, B.D.; Li, X.; Bhardwaj, P.; Palmer, K.L. Comparative analysis of the orphan CRISPR2 locus in 242 Enterococcus faecalis strains. PLoS ONE 2015, 10, e0138890. [CrossRef] [PubMed]

26. Lindenstrauß, A.G.; Pavlovic, M.; Bringmann, A.; Behr, J.; Ehrmann, M.A.; Vogel, R.F. Comparison of genotypic and phenotypic cluster analyses of virulence determinants and possible role of CRISPR elements towards their incidence in Enterococcus faecalis and Enterococcus faecium. Syst. Appl. Microbiol. 2011, 34, 553-560. [CrossRef] [PubMed] 
27. Price, V.J.; Huo, W.; Sharifi, A.; Palmer, K.L. CRISPR-cas and restriction-modification act additively against conjugative antibiotic resistance plasmid transfer in Enterococcus faecalis. mSphere 2016, 1. [CrossRef] [PubMed]

28. Huo, W.; Adams, H.M.; Zhang, M.Q.; Palmer, K.L. Genome modification in Enterococcus faecalis OG1RF assessed by bisulfite sequencing and single-molecule real-time sequencing. J. Bacteriol. 2015, 197, 1939-1951. [CrossRef] [PubMed]

29. Palmer, K.L.; Gilmore, M.S. Multidrug-resistant enterococci lack CRISPR-cas. MBio 2010, 1, e00227-10. [CrossRef] [PubMed]

30. Hullahalli, K.; Rodrigues, M.; Nguyen, U.T.; Palmer, K. An attenuated CRISPR-cas system in Enterococcus faecalis permits DNA acquisition. MBio 2018, 9, e00414-18. [CrossRef]

31. Villarreal, L.P. Viral ancestors of antiviral systems. Viruses 2011, 3, 1933-1958. [CrossRef]

32. Arber, W.; Dussoix, D. Host specificity of DNA produced by Escherichia coli. I. Host controlled modification of bacteriophage lambda. J. Mol. Biol. 1962, 5, 18-36. [CrossRef]

33. Seed, K.D.; Lazinski, D.W.; Calderwood, S.B.; Camilli, A. A bacteriophage encodes its own CRISPR/cas adaptive response to evade host innate immunity. Nature 2013, 494, 489-491. [CrossRef]

34. Nilsson, A.S.; Karlsson, J.L.; Haggård-Ljungquist, E. Site-specific recombination links the evolution of P2-like coliphages and pathogenic enterobacteria. Mol. Biol. Evol. 2004, 21, 1-13. [CrossRef]

35. Kintz, E.; Davies, M.R.; Hammarlöf, D.L.; Canals, R.; Hinton, J.C.D.; van der Woude, M.W. A BTP1 prophage gene present in invasive non-typhoidal Salmonella determines composition and length of the O-antigen of the lipopolysaccharide. Mol. Microbiol. 2015, 96, 263-275. [CrossRef] [PubMed]

36. Cumby, N.; Edwards, A.M.; Davidson, A.R.; Maxwell, K.L. The bacteriophage HK97 gp15 moron element encodes a novel superinfection exclusion protein. J. Bacteriol. 2012, 194, 5012-5019. [CrossRef] [PubMed]

37. Mahony, J.; McGrath, S.; Fitzgerald, G.F.; van Sinderen, D. Identification and characterization of lactococcal-prophage-carried superinfection exclusion genes. Appl. Environ. Microbiol. 2008, 74, 6206-6215. [CrossRef] [PubMed]

38. Bebeacua, C.; Lorenzo Fajardo, J.C.; Blangy, S.; Spinelli, S.; Bollmann, S.; Neve, H.; Cambillau, C.; Heller, K.J. $\mathrm{X}$-ray structure of a superinfection exclusion lipoprotein from phage TP-J34 and identification of the tape measure protein as its target. Mol. Microbiol. 2013, 89, 152-165. [CrossRef] [PubMed]

39. Bondy-Denomy, J.; Qian, J.; Westra, E.R.; Buckling, A.; Guttman, D.S.; Davidson, A.R.; Maxwell, K.L. Prophages mediate defense against phage infection through diverse mechanisms. ISME J. 2016, 10, 2854-2866. [CrossRef] [PubMed]

40. Dedrick, R.M.; Jacobs-Sera, D.; Bustamante, C.A.G.; Garlena, R.A.; Mavrich, T.N.; Pope, W.H.; Reyes, J.C.C.; Russell, D.A.; Adair, T.; Alvey, R.; et al. Prophage-mediated defence against viral attack and viral counter-defence. Nat. Microbiol. 2017, 2, 16251. [CrossRef] [PubMed]

41. Parma, D.H.; Snyder, M.; Sobolevski, S.; Nawroz, M.; Brody, E.; Gold, L. The Rex system of bacteriophage lambda: Tolerance and altruistic cell death. Genes Dev. 1992, 6, 497-510. [CrossRef] [PubMed]

42. Friedman, D.I.; Mozola, C.C.; Beeri, K.; Ko, C.-C.; Reynolds, J.L. Activation of a prophage-encoded tyrosine kinase by a heterologous infecting phage results in a self-inflicted abortive infection. Mol. Microbiol. 2011, 82, 567-577. [CrossRef]

43. Matos, R.C.; Lapaque, N.; Rigottier-Gois, L.; Debarbieux, L.; Meylheuc, T.; Gonzalez-Zorn, B.; Repoila, F.; de Lopes, M.F.; Serror, P. Enterococcus faecalis prophage dynamics and contributions to pathogenic traits. PLoS Genet. 2013, 9, e1003539. [CrossRef]

44. Jurczak-Kurek, A.; Gąsior, T.; Nejman-Faleńczyk, B.; Bloch, S.; Dydecka, A.; Topka, G.; Necel, A.; Jakubowska-Deredas, M.; Narajczyk, M.; Richert, M.; et al. Biodiversity of bacteriophages: Morphological and biological properties of a large group of phages isolated from urban sewage. Sci. Rep 2016, 6, 34338. [CrossRef]

45. Dumoulin, R.; Cortes-Perez, N.; Gaubert, S.; Duhutrel, P.; Brinster, S.; Torelli, R.; Sanguinetti, M.; Posteraro, B.; Repoila, F.; Serror, P. Enterococcal Rgg-like regulator ElrR activates expression of the elrA operon. J. Bacteriol. 2013, 195, 3073-3083. [CrossRef]

46. Gasson, M.J. Plasmid complements of Streptococcus lactis NCDO 712 and other lactic streptococci after protoplast-induced curing. J. Bacteriol. 1983, 154, 1-9. [PubMed]

47. Renault, P.; Corthier, G.; Goupil, N.; Delorme, C.; Ehrlich, S.D. Plasmid vectors for gram-positive bacteria switching from high to low copy number. Gene 1996, 183, 175-182. [CrossRef] 
48. Rigottier-Gois, L.; Alberti, A.; Houel, A.; Taly, J.-F.; Palcy, P.; Manson, J.; Pinto, D.; Matos, R.C.; Carrilero, L.; Montero, N.; et al. Large-scale screening of a targeted Enterococcus faecalis mutant library identifies envelope fitness factors. PLoS ONE 2011, 6, e29023. [CrossRef]

49. Rigottier-Gois, L.; Madec, C.; Navickas, A.; Matos, R.C.; Akary-Lepage, E.; Mistou, M.-Y.; Serror, P. The surface rhamnopolysaccharide Epa of Enterococcus faecalis is a key determinant of intestinal colonization. J. Infect. Dis. 2015, 211, 62-71. [CrossRef]

50. Sahm, D.F.; Marsilio, M.K.; Piazza, G. Antimicrobial resistance in key bloodstream bacterial isolates: Electronic surveillance with the Surveillance Network Database-USA. Clin. Infect. Dis. 1999, 29, 259-263. [CrossRef] [PubMed]

51. Fritzenwanker, M.; Kuenne, C.; Billion, A.; Hain, T.; Zimmermann, K.; Goesmann, A.; Chakraborty, T.; Domann, E. Complete Genome Sequence of the Probiotic Enterococcus faecalis Symbioflor 1 Clone DSM 16431. Genome Announc. 2013, 1, e00165-12. [CrossRef] [PubMed]

52. Jamet, E.; Akary, E.; Poisson, M.-A.; Chamba, J.-F.; Bertrand, X.; Serror, P. Prevalence and characterization of antibiotic resistant Enterococcus faecalis in French cheeses. Food Microbiol. 2012, 31, 191-198. [CrossRef]

53. Fortier, L.-C.; Moineau, S. Phage production and maintenance of stocks, including expected stock lifetimes. Methods Mol. Biol. 2009, 501, 203-219. [PubMed]

54. Pickard, D.J.J. Preparation of bacteriophage lysates and pure DNA. Methods Mol. Biol. 2009, 502, 3-9.

55. Summer, E.J. Preparation of a phage DNA fragment library for whole genome shotgun sequencing. Methods Mol. Biol. 2009, 502, 27-46. [PubMed]

56. Margulies, M.; Egholm, M.; Altman, W.E.; Attiya, S.; Bader, J.S.; Bemben, L.A.; Berka, J.; Braverman, M.S.; Chen, Y.-J.; Chen, Z.; et al. Genome sequencing in microfabricated high-density picolitre reactors. Nature 2005, 437, 376-380. [CrossRef] [PubMed]

57. Aziz, R.K.; Bartels, D.; Best, A.A.; DeJongh, M.; Disz, T.; Edwards, R.A.; Formsma, K.; Gerdes, S.; Glass, E.M.; Kubal, M.; et al. The RAST Server: Rapid annotations using subsystems technology. BMC Genom. 2008, 9, 75. [CrossRef] [PubMed]

58. Sullivan, M.J.; Petty, N.K.; Beatson, S.A. Easyfig: A genome comparison visualizer. Bioinformatics 2011, 27, 1009-1010. [CrossRef]

59. Hyman, P.; Abedon, S.T. Practical methods for determining phage growth parameters. Methods Mol. Biol. 2009, 501, 175-202.

60. Garvey, P.; Hill, C.; Fitzgerald, G.F. The lactococcal plasmid pNP40 encodes a third bacteriophage resistance mechanism, one which affects phage DNA penetration. Appl. Environ. Microbiol. 1996, 62, 676-679.

61. Sing, W.D.; Klahenhammer, T.R. Characteristics of phage abortion conferred in lactococci by the congugal plasmid pTR2030. J. Mol. Biol. 1990, 136, 1807-1815.

62. Behnke, D.; Malke, H. Bacteriophage interference in Streptococcus pyogenes. II. A25 mutants resistant to prophage-medicated interference. Virology 1978, 85, 129-136. [CrossRef]

63. Luria, S.E.; Delbrück, M. Mutations of bacteria from virus sensitivity to virus resistance. Genetics 1943, 28, 491-511.

64. Dower, W.J.; Miller, J.F.; Ragsdale, C.W. High efficiency transformation of E. coli by high voltage electroporation. Nucleic Acids Res. 1988, 16, 6127-6145. [CrossRef]

65. Dunny, G.M.; Lee, L.N.; LeBlanc, D.J. Improved electroporation and cloning vector system for gram-positive bacteria. Appl. Environ. Microbiol. 1991, 57, 1194-1201. [PubMed]

66. Brinster, S.; Furlan, S.; Serror, P. C-terminal WxL domain mediates cell wall binding in Enterococcus faecalis and other gram-positive bacteria. J. Bacteriol. 2007, 189, 1244-1253. [CrossRef] [PubMed]

67. Blanco, L.; Salas, M. Relating structure to function in phi29 DNA polymerase. J. Biol. Chem. 1996, 271, 8509-8512. [CrossRef] [PubMed]

68. Dufour, E.; Méndez, J.; Lázaro, J.M.; de Vega, M.; Blanco, L.; Salas, M. An aspartic acid residue in TPR-1, a specific region of protein-priming DNA polymerases, is required for the functional interaction with primer terminal protein1. J. Mol. Biol. 2000, 304, 289-300. [CrossRef] [PubMed]

69. Eisenbrandt, R.; Lázaro, J.M.; Salas, M.; Vega, M. de. Phi29 DNA polymerase residues Tyr59, His61 and Phe69 of the highly conserved ExoII motif are essential for interaction with the terminal protein. Nucleic Acids Res. 2002, 30, 1379-1386. [CrossRef]

70. Meijer, W.J.J.; Horcajadas, J.A.; Salas, M. $\varphi 29$ Family of Phages. Microbiol. Mol. Biol. Rev. 2001, 65, $261-287$. [CrossRef] 
71. Rodríguez, I.; Lázaro, J.M.; Blanco, L.; Kamtekar, S.; Berman, A.J.; Wang, J.; Steitz, T.A.; Salas, M.; de Vega, M. A specific subdomain in phi29 DNA polymerase confers both processivity and strand-displacement capacity. Proc. Natl. Acad. Sci. USA 2005, 102, 6407-6412. [CrossRef]

72. Redrejo-Rodríguez, M.; Salas, M. Multiple roles of genome-attached bacteriophage terminal proteins. Virology 2014, 468-470, 322-329. [CrossRef]

73. Redrejo-Rodríguez, M.; Muñoz-Espín, D.; Holguera, I.; Mencía, M.; Salas, M. Nuclear and nucleoid localization are independently conserved functions in bacteriophage terminal proteins. Mol. Microbiol. 2013, 90, 858-868. [CrossRef] [PubMed]

74. Bateman, A.; Rawlings, N.D. The CHAP domain: A large family of amidases including GSP amidase and peptidoglycan hydrolases. Trends Biochem. Sci. 2003, 28, 234-237. [CrossRef]

75. McGowan, S.; Buckle, A.M.; Mitchell, M.S.; Hoopes, J.T.; Gallagher, D.T.; Heselpoth, R.D.; Shen, Y.; Reboul, C.F.; Law, R.H.P.; Fischetti, V.A.; et al. X-ray crystal structure of the streptococcal specific phage lysin PlyC. Proc. Natl. Acad. Sci. USA 2012, 109, 12752-12757. [CrossRef] [PubMed]

76. Rigden, D.J.; Jedrzejas, M.J.; Galperin, M.Y. Amidase domains from bacterial and phage autolysins define a family of gamma-D,L-glutamate-specific amidohydrolases. Trends Biochem. Sci. 2003, 28, 230-234. [CrossRef]

77. Nelson, D.; Schuch, R.; Chahales, P.; Zhu, S.; Fischetti, V.A. PlyC: A multimeric bacteriophage lysin. Proc. Natl. Acad. Sci. USA 2006, 103, 10765-10770. [CrossRef] [PubMed]

78. Lavigne, R.; Seto, D.; Mahadevan, P.; Ackermann, H.-W.; Kropinski, A.M. Unifying classical and molecular taxonomic classification: Analysis of the Podoviridae using BLASTP-based tools. Res. Microbiol. 2008, 159, 406-414. [CrossRef] [PubMed]

79. McGrath, S.; Fitzgerald, G.F.; van Sinderen, D. Identification and characterization of phage-resistance genes in temperate lactococcal bacteriophages. Mol. Microbiol. 2002, 43, 509-520. [CrossRef] [PubMed]

80. Innocenti, N.; Golumbeanu, M.; d' Hérouël, A.F.; Lacoux, C.; Bonnin, R.A.; Kennedy, S.P.; Wessner, F.; Serror, P.; Bouloc, P.; Repoila, F.; et al. Whole-genome mapping of $5^{\prime}$ RNA ends in bacteria by tagged sequencing: A comprehensive view in Enterococcus faecalis. Rna 2015, 21, 1018-1031. [CrossRef] [PubMed]

81. Chopin, M.-C.; Chopin, A.; Bidnenko, E. Phage abortive infection in lactococci: Variations on a theme. Curr. Opin. Microbiol. 2005, 8, 473-479. [CrossRef]

82. Paez-Espino, D.; Roux, S.; Chen, I.-M.A.; Palaniappan, K.; Ratner, A.; Chu, K.; Huntemann, M.; Reddy, T.B.K.; Pons, J.C.; Llabrés, M.; et al. IMG/VR v.2.0: An integrated data management and analysis system for cultivated and environmental viral genomes. Nucleic Acids Res. 2018. [CrossRef]

83. Nelson, D.; Schuch, R.; Zhu, S.; Tscherne, D.M.; Fischetti, V.A. Genomic sequence of C1, the first streptococcal phage. J. Bacteriol. 2003, 185, 3325-3332. [CrossRef]

84. Palmer, K.L.; Godfrey, P.; Griggs, A.; Kos, V.N.; Zucker, J.; Desjardins, C.; Cerqueira, G.; Gevers, D.; Walker, S.; Wortman, J.; et al. Comparative genomics of enterococci: Variation in Enterococcus faecalis, clade structure in E. faecium, and defining characteristics of E. gallinarum and E. casseliflavus. MBio 2012, 3, e00318-11. [CrossRef]

85. Nelson, D.C.; Schmelcher, M.; Rodriguez-Rubio, L.; Klumpp, J.; Pritchard, D.G.; Dong, S.; Donovan, D.M. Endolysins as antimicrobials. Adv. Virus Res. 2012, 83, 299-365. [PubMed]

86. Cheng, M.; Zhang, Y.; Li, X.; Liang, J.; Hu, L.; Gong, P.; Zhang, L.; Cai, R.; Zhang, H.; Ge, J.; et al. Endolysin LysEF-P10 shows potential as an alternative treatment strategy for multidrug-resistant Enterococcus faecalis infections. Sci. Rep. 2017, 7, 10164. [CrossRef] [PubMed]

87. Chowdhury, R.; Biswas, S.K.; Das, J. Abortive replication of choleraphage phi 149 in Vibrio cholerae biotype el tor. J. Virol. 1989, 63, 392-397. [PubMed]

88. Rettenmier, C.W.; Hemphill, H.E. Abortive infection of lysogenic Bacillus subtilis 168(SPO2) by bacteriophage phi 1. J. Virol. 1974, 13, 870-880. [PubMed]

89. Smith, H.S.; Pizer, L.I.; Pylkas, L.; Lederberg, S. Abortive infection of Shigella dysenteriae P2 by T2 bacteriophage. J. Virol. 1969, 4, 162-168. [PubMed]

90. Tran, L.S.; Szabó, L.; Ponyi, T.; Orosz, L.; Sík, T.; Holczinger, A. Phage abortive infection of Bacillus licheniformis ATCC 9800; identification of the abiBL11 gene and localisation and sequencing of its promoter region. Appl. Microbiol. Biotechnol. 1999, 52, 845-852. [CrossRef] [PubMed]

91. Snyder, L. Phage-exclusion enzymes: A bonanza of biochemical and cell biology reagents? Mol. Microbiol. 1995, 15, 415-420. [CrossRef] 
92. Stern, A.; Sorek, R. The phage-host arms race: Shaping the evolution of microbes. Bioessays 2011, 33, 43-51. [CrossRef]

93. Durmaz, E.; Klaenhammer, T.R. Abortive phage resistance mechanism AbiZ speeds the lysis clock to cause premature lysis of phage-infected Lactococcus lactis. J. Bacteriol. 2007, 189, 1417-1425. [CrossRef]

94. Young, R. Phage lysis: Three steps, three choices, one outcome. J. Microbiol. 2014, 52, 243-258. [CrossRef]

95. Wang, I.N.; Smith, D.L.; Young, R. Holins: The protein clocks of bacteriophage infections. Annu. Rev. Microbiol. 2000, 54, 799-825. [CrossRef] [PubMed]

96. Ho, K.; Huo, W.; Pas, S.; Dao, R.; Palmer, K.L. Loss-of-Function Mutations in epaR Confer Resistance to фNPV1 Infection in Enterococcus faecalis OG1RF. Antimicrob. Agents Chemother. 2018, 62. [CrossRef] [PubMed]

97. Teng, F.; Singh, K.V.; Bourgogne, A.; Zeng, J.; Murray, B.E. Further characterization of the epa gene cluster and Epa polysaccharides of Enterococcus faecalis. Infect. Immun. 2009, 77, 3759-3767. [CrossRef] [PubMed]

98. Chapot-Chartier, M.-P. Interactions of the cell-wall glycopolymers of lactic acid bacteria with their bacteriophages. Front. Microbiol. 2014, 5, 236. [CrossRef] [PubMed]

99. Mistou, M.-Y.; Sutcliffe, I.C.; van Sorge, N.M. Bacterial glycobiology: Rhamnose-containing cell wall polysaccharides in Gram-positive bacteria. FEMS Microbiol. Rev. 2016, 40, 464-479. [CrossRef]

100. Ainsworth, S.; Sadovskaya, I.; Vinogradov, E.; Courtin, P.; Guerardel, Y.; Mahony, J.; Grard, T.; Cambillau, C.; Chapot-Chartier, M.-P.; van Sinderen, D. Differences in lactococcal cell wall polysaccharide structure are major determining factors in bacteriophage sensitivity. MBio 2014, 5, e00880-14. [CrossRef]

(C) 2019 by the authors. Licensee MDPI, Basel, Switzerland. This article is an open access article distributed under the terms and conditions of the Creative Commons Attribution (CC BY) license (http://creativecommons.org/licenses/by/4.0/). 